\title{
UNIVERSITYOF
}

FORWARD

THINKING

WESTMINSTER用

WestminsterResearch

http://www.westminster.ac.uk/westminsterresearch

\section{A tale of two cinnamons: a comparative review of the clinical evidence of Cinnamomum verum and C.cassia as diabetes interventions}

Shinjiyo, N., Waddell, G. and Green, J.

NOTICE: this is the authors' version of a work that was accepted for publication in Journal of Herbal Medicine. Changes resulting from the publishing process, such as peer review, editing, corrections, structural formatting, and other quality control mechanisms may not be reflected in this document. Changes may have been made to this work since it was submitted for publication. A definitive version was subsequently published in Journal of Herbal Medicine, DOI: 10.1016/j.hermed.2020.100342, 2020.

The final definitive version in Journal of Herbal Medicine is available online at:

https://dx.doi.org/10.1016/..hermed.2020.100342

(c) 2020. This manuscript version is made available under the CC-BY-NC-ND 4.0 license https://creativecommons.org/licenses/by-nc-nd/4.0/

The WestminsterResearch online digital archive at the University of Westminster aims to make the research output of the University available to a wider audience. Copyright and Moral Rights remain with the authors and/or copyright owners.

Whilst further distribution of specific materials from within this archive is forbidden, you may freely distribute the URL of WestminsterResearch: ((http://westminsterresearch.wmin.ac.uk/)).

In case of abuse or copyright appearing without permission e-mail repository@westminster.ac.uk 


\section{Journal Pre-proof}

A tale of two cinnamons: a comparative review of the clinical evidence of Cinnamomum verum and $C$. cassia as diabetes interventions

Noriko Shinjyo, Guy Waddell, Julia Green

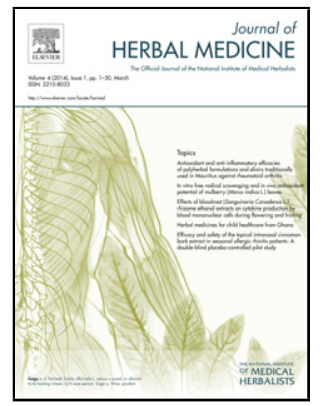

PII:

S2210-8033(20)30014-2

DOI:

https://doi.org/10.1016/j.hermed.2020.100342

Reference:

HERMED 100342

To appear in:

Journal of Herbal Medicine

Received Date:

17 June 2018

Revised Date:

16 July 2019

Accepted Date:

10 February 2020

Please cite this article as: Shinjyo N, Waddell G, Green J, A tale of two cinnamons: a comparative review of the clinical evidence of Cinnamomum verum and $C$. cassia as diabetes interventions, Journal of Herbal Medicine (2020),

doi: https://doi.org/10.1016/j.hermed.2020.100342

This is a PDF file of an article that has undergone enhancements after acceptance, such as the addition of a cover page and metadata, and formatting for readability, but it is not yet the definitive version of record. This version will undergo additional copyediting, typesetting and review before it is published in its final form, but we are providing this version to give early visibility of the article. Please note that, during the production process, errors may be discovered which could affect the content, and all legal disclaimers that apply to the journal pertain.

(C) 2019 Published by Elsevier. 
Systematic Review Article

\section{Title:}

A tale of two cinnamons: a comparative review of the clinical evidence of Cinnamomum verum and C. cassia as diabetes interventions

Noriko Shinjyo $^{1,2}$, Guy Waddell ${ }^{3}$, and Julia Green ${ }^{3}$

${ }^{1}$. Department of Infection and Host Defence, Graduate School of Medicine, Chiba University, 1-8-1 Inohana, Chuo-ku, Chiba 260-8670, Japan

${ }^{2}$. Division of Molecular and Cellular Immunoscience, Department of Biomolecular Sciences, Faculty of Medicine, Saga University, 5-1-1 Nabeshima, Saga 849-8501, Japan

${ }^{3}$. Department of Life Sciences, Faculty of Science and Technology at the University of Westminster, 115 New Cavendish Street London W1W 6UW, United Kingdom

E-mail addresses (Noriko Shinjyo):

nshinjyo@chiba-u.jp

nrkshinjyo@gmail.com

\section{Abstract}

Objective: This review investigates the effectiveness of two cinnamon species, Cinnamomum verum and $C$. cassia, in diabetes management; their impact on related health conditions and relevant parameters in healthy individuals and safety issues.

Methods: PubMed, Cochrane Library, and ScienceDirect were searched from 2000 up to April 2018 for clinical trials using either C. verum or C. cassia in controlling blood glucose and other diabetes-related parameters and conditions.

Results: A total of twenty-five studies ( $\mathrm{n}=997)$ were included for reviewing clinical evidence. Among these trials, fifteen studies investigated the effects on type II diabetes mellitus 
(T2DM) patients ( $\mathrm{n}=831)$, four investigated subjects with related clinical conditions $(\mathrm{n}=82)$, and six investigated healthy individuals $(\mathrm{n}=84)$. Nineteen studies used $C$. cassia and six used C. verum. Results suggested $C$. cassia helped manage diabetes at 3-6g, while the effectiveness of $C$. verum remained inconclusive. In addition, the chemical properties of $C$. cassia and C. verum differ considerably. Of note, C. cassia contains high levels of the potentially hepatotoxic constituent coumarin. A skin rash was the only adverse event reported.

Conclusion: While evidence supports the therapeutic benefit of C. cassia, interchangeability of $C$. cassia and $C$. verum remains inconclusive. Further research is warranted to address the effectiveness and safety of these cinnamon species. Given the potential hepatotoxicity of $C$. cassia, RCTs that include liver function tests are required. Robust RCTs on C. verum are recommended to establish if its efficacy can match its safety profile.

Keywords: cinnamon, Cinnamomum verum, Cinnamomum cassia, diabetes

\section{Introduction}

The number of diabetes sufferers has been increasing. In 2014, globally, 422 million people were living with diabetes, compared with 108 million in 1980, according to the World Health Organization (WHO, 2016). Diabetes is a metabolic disorder affecting blood glucose levels, which can have serious consequences, including cardiovascular disease, nephropathy, retinopathy, peripheral neuropathy and diabetic foot (Struijs et al., 2006; WHO, 2016). The majority of diabetes patients are affected by type II diabetes mellitus (T2DM), which mainly occurs among adults and is associated with insulin resistance, metabolic syndrome and obesity (Kahn et al., 2006). Growing evidence suggests the association between insulin resistance and several clinical conditions, including polycystic ovarian syndrome (PCOS) (Pauli et al., 2011), non-alcoholic fatty liver disease (NAFLD) (Ballestri et al., 2016), various cancers (Malaguarnera et al., 2017; Vona-Davis et al., 2007) and their complications (e.g. muscle wasting cachexia (Honors and Kinzig, 2012)). In addition, epidemiological evidence 
suggests that people with diabetes are at an increased risk for cognitive decline, vascular dementia, and Alzheimer's disease (Gudala et al., 2013; Ninomiya, 2014; Ojo and Brooke, 2015), indicating the importance of diabetes management in the ageing population.

Due to the increasing prevalence and chronic nature, T2DM is a global health issue of significant economic importance. According to American Diabetes Association (ADA), the direct medical cost in 2012 was $\$ 176$ billion in the United States, and average medical expenditure on a diabetes patient was about $\$ 13,700$ per year: approximately 2.3 times higher than the estimate in the absence of diabetes (ADA, 2013). In Europe, a study comprising 8 countries (Belgium, France, Germany, Italy, the Netherlands, Spain, Sweden and the United Kingdom) revealed the cost of T2DM to be $€ 29$ billion a year (1999 values) and the estimated average yearly cost $€ 2834$ per patient (Jönsson B and Board., 2002). In Germany alone, average annual direct cost of medical care was $€ 5,262$, approximately 1.9 times higher compared with costs of age- and sex-matched non-diabetic control subjects (Köster et al., 2006). Although some of the top-selling medications such as metformin are modestly priced and drug costs for managing T2DM are relatively low (7\% of the total healthcare costs for T2DM) (Jönsson B and Board., 2002), the exploration of blood glucose management using traditional herbal medicines is warranted as it could help prevent the development of T2DM and comorbidities, thereby reducing the direct and indirect costs. Current anti-diabetic drugs such as sulfonylureas and $\alpha$-glucosidase inhibitors help manage blood glucose levels. However, due to potential side effects such as nausea, dyspepsia and weight gain (Sola et al., 2015; van de Laar, 2008), it is important to find effective and safer alternatives.

The medicinal properties of cinnamon have been acknowledged since antiquity (De Vos, 2010). The genus Cinnamomum (Lauraceae) includes more than 250 species, among which Cinnamomum verum J.Presl (synonym: C. zeylanicum Blume, Ceylon cinnamon or true cinnamon) and $C$. cassia (L.) J.Presl (synonym: C. aromaticum Nees, cassia cinnamon or Chinese cinnamon) are most commonly used as medicines (Nabavi et al., 2015). The inner bark is used as a circulatory stimulant, a digestive aid, diaphoretic, and antitussive (Bone and 
Mills, 2013; Klein and Rister, 1993). Historically, C. cassia is among the top 14 'simples' (plants that can be used on their own for medicinal purposes, rather than as part of a formula) listed in 12 important texts including Hippocratic Corpus $\left(5^{\text {th }}-4^{\text {th }}\right.$ century BC), De Materia Medica by Dioscorides ( $1^{\text {st }}$ century AD), The Canon of Medicine (volume 2) by Avicenna (980 - 1037 AD), and Farmacopea Espanola (1865), while C. verum is one of the top 26 simples, listed in 11 out of the 12 texts (De Vos, 2010). In The Canon of Medicine, Cinnamomum spp. was among 18 plants that protect the liver from injuries or diseases, and recent studies confirmed the hepatoprotective effect of Cinnamomum spp. using animal models (Shamsi-Baghbanan et al., 2014). In a 15th-century French herbal 'Le Livre des Simples Medecines', cinnamon was among the six medicinal spices (pepper, ginger, cinnamon, cloves, nutmeg, and mace). The text states that cinnamon is used 'for weakness of the stomach and liver and to help digestion weakened by cold', 'to restore appetite', 'for recently cracked lips and other sores', and 'for heart ailments and syncope' (Nam, 2014). In fact, the use of cinnamon to treat digestive tract ailments has continued throughout history (De Vos, 2010). The European Medicine Agency (EMA) endorses the traditional use of $C$. verum for symptomatic treatment of mild, spasmodic gastro-intestinal complaints (EMA, 2011b). At present, cinnamon is on the market as a prophylactic supplement for metabolic syndrome, insulin resistance, T2DM, hyperlipidaemia, and arthritis (Medagama, 2015; Rafehi et al., 2012).

The major constituents of cinnamon include cinnamaldehyde, cinnamyl acetate, eugenol, catechin, epicatechin, and proanthocyanidins (Chen et al., 2012; Chen et al., 2014; Kaul et al., 2003; Vallverdú-Queralt et al., 2014). A number of potential mechanisms for cinnamon have been suggested (Rafehi et al., 2012), including activation of phosphorylation of insulin receptors $\beta$-subunits; increased expression of GLUT 4, increase in GLUT 1 mediated glucose uptake, increase in GLP-1, increase in PPAR, inhibition of intestinal $\alpha$ glucosidase and pancreatic $\alpha$-amylase, inhibition of gluconeogenesis, and delay of gastric emptying. Preclinical studies demonstrated hypoglycaemic and hypolipidaemic properties of 
cinnamon extract and the active constituents (Medagama, 2015). In vivo studies found improved insulin sensitivity and lowered intestinal carbohydrate absorption after the treatment with cinnamon extract in T2DM model mice (Kim et al., 2006), a reduction of plasma glucose levels by cinnamaldehyde via insulin secretion from pancreatic $\beta$-cells (Subash Babu et al., 2007), insulin-like activity of cinnamon polyphenols (trimers and tetramers of catechin and epicatechin) (Anderson et al., 2004), blood glucose-lowering effects of polyphenol-enriched C. verum extract (IM et al., 2014b) and polyphenol-enriched decoumarinated C. cassia extract (IM et al., 2014a), and lowered triglyceride and total cholesterol levels after treatment with cinnamon extract in T2DM model mice (Kim et al., 2006). PPAR- $\gamma$ and $\alpha$ activation in adipocytes (Sheng et al., 2008) and up-regulation of antiinflammatory factors such as tristetraprolin and glucose transporter (GLUT1) in macrophages were also suggested in vitro (Cao et al., 2008). Using C. verum, Kadan et al. demonstrated a significant gain in GLUT4 on the cell surface of muscle cells, suggesting that $C$. verum could facilitate glucose uptake into skeletal muscle (Kadan et al., 2013). Considering that glycemic fluctuations and hyperglycemia trigger endothelial dysfunction and inflammation (Mannucci et al., 2013), controlling hyperglycemia is likely to reduce the risk of atherogenesis and cardiovascular events. In addition, hyperglycemia and abnormal insulin levels are related to an increased risk of Alzheimer's disease as well as vascular dementia (Gudala et al., 2013; Matsuzaki et al., 2010; Rönnemaa et al., 2008; Young et al., 2006). Therefore, the hypoglycaemic property of cinnamon may protect against diabetes-related comorbidities such as cardiovascular diseases and dementia.

The EMA states that cinnamon bark contains up to $4 \%$ of essential oil consisting primarily of cinnamaldehyde (60-75\%) (EMA, 2011a). Herbal preparations equivalent to 2-4g cinnamon per day, or 50-200mg of essential oil, are indicated for symptomatic treatment of mild spasmodic gastrointestinal complaints including bloating and flatulence (EMA, 2011b). C. cassia has traditional use similar to $C$. verum, however the two species have differences in their constituents as summarised elsewhere (Ranasinghe et al., 2013): C. verum bark oil 
contains $49.9-62.8 \%$ trans-cinnamaldehyde while C. cassia contains almost $95 \%$

cinnamaldehyde. In addition, it is notable that $C$. cassia contains coumarin up to $1 \%$ (Krieger et al., 2013), whereas $C$. verum contains coumarin only at trace or undetectable levels (Krieger et al., 2013; Ranasinghe et al., 2013). Considering that $o$ hydroxyphenylacetaldehyde (o-HPA), a metabolite of coumarin, is hepatotoxic, long-term consumption of $C$. cassia may pose a health risk (Abraham et al., 2010; Ranasinghe et al., 2013), while $C$. verum would likely be free of this particular risk (Medagama, 2015).

Therefore it has been suggested that $C$. verum should be used in preference to $C$. cassia in treating T2DM (Medagama, 2015).

Five reviews have examined the efficacy of cinnamon species for diabetes (Table 1). A systematic review and meta-analysis conducted in 2012 (Leach and Kumar, 2012) assessed ten RCTs published between 2003 and 2010. The authors concluded that there is insufficient evidence to support the use of cinnamon as an anti-diabetes mellitus treatment. On the other hand, systematic review and meta-analysis by Akilen et al.(2012) found a significant decrease in HbA1c and fasting blood glucose levels (Akilen et al., 2012). A year later, In 2013, a meta-analysis (Allen et al., 2013) found significant improvement in fasting blood glucose levels as well as in lipid parameters, although no significant effect was found on HbA1c levels. Another meta-analysis (Alanazi and Khan, 2015) reflected the findings of Allen et al. (2013). Medagama (2015) found improved glycaemic control in T2DM patients without other medications as well as those with pre-diabetes and high pre-treatment $\mathrm{HbA1c}$. Medagama concluded that cinnamon is potentially useful as an adjuvant therapy in managing T2DM. The difference in conclusions between those reviews is interesting, ranging from insufficient evidence to a useful add on treatment. Of note, none of these reviews separately assessed the different cinnamon species. Overall this suggests the evidence for effective intervention in T2DM is growing, but provisional, given the heterogeneity of cinnamon species, preparations, and dosages.

The herbal CONSORT statement (Gagnier et al., 2006) considers it "imperative that reports of RCTs provide clear and complete descriptions of the herbal intervention", 
including the Latin binomial name together with botanical authority and family name in addition to common names for each herbal ingredient. If the species is unspecified it is difficult to establish causality. Given the potential confusion, substitution or adulteration of herbal products, (Fong, 2002; Posadzki et al., 2012), this review focuses on interventions using two named cinnamon species: C. cassia and C. verum.

While Medagama discussed the safety issue of high coumarin content in $C$ cassia, suggesting $C$. verum syn zeylanicum as a safer alternative, none of the five reviews evaluated the differential efficacy of the two main medicinal cinnamon species and their dosages as a T2DM intervention and whether the coumarin content of these species is a cause for concern. Furthermore, these reviews did not assess the differential evidence for the suitability of the two cinnamon species for related clinical conditions, nor the effect of the two cinnamon species on blood sugar related parameters in healthy populations. Hence, this study seeks to review the current evidence for $C$. cassia and $C$. verum in the treatment of T2DM and metabolically related conditions, their effects on blood sugar related parameters in healthy populations, and their safety profile.

\section{Methods}

2.1 Database searching for clinical evidence

The current review focuses on trials investigating the effects of $C$. verum and $C$. cassia on the levels of blood glucose and other relevant parameters in diabetes management. To consider prophylactic benefits and effectiveness in the management of diabetes, trials on T2DM patients, as well as subjects with other related clinical conditions and healthy individuals, were reviewed.

Search strategy

To find clinical evidence for the anti-diabetic effects of $C$. verum and $C$. cassia, searches were conducted using databases, namely PubMed/Medline, Cochrane Library, and ScienceDirect. Studies were included in the current review if they were published between 2000 up to April 2018 and met the inclusion criteria below. PubMed/Medline searches were conducted for 
article type 'Clinical Trial', using search terms 'Cinnamomum verum' and its botanical synonym 'Cinnamomum zeylanicum', 'Cinnamomum cassia', and its botanical synonym

'Cinnamomum aromaticum'. The same terms were used for searching in Cochrane Library, and ScienceDirect. For ScienceDirect, searches were refined by selecting 'Abstract, Title, Keywords' and categories of 'Nursing and Dentistry', 'Nursing and Health Professions', 'Pharmacology', and 'Toxicology and Pharmaceutical Science'.

Inclusion criteria:

1. Original study

2. Focusing on the effect of either $C$. verum or $C$. cassia (not in combination with other herbs or nutrients) in controlling blood glucose levels or other parameters relevant to diabetes management or related clinical conditions

3. Published in English

4. Controlled

Publications not meeting the above criteria, as well as studies using unspecified or different cinnamon species, or combination products, were excluded. Each author assessed the final selection of studies independently, before final agreement on inclusion.

\subsection{Coumarin content and safety issues}

To assess coumarin contents and potential toxicity of cinnamon species, database searches were conducted for journal articles using the combination of 2 keywords, namely coumarin and either $C$. verum or $C$. cassia. PubMed searches were conducted using the following search terms: (1) (Cinnamomum zeylanicum) AND coumarin, (2) (Cinnamomum verum) AND coumarin, (3) (Cinnamomum cassia) AND coumarin, and (4) (Cinnamomum aromaticum) AND coumarin, for publication from 1971 to November 2017. For ScienceDirect, the same term combinations were searched in abstract, title, and keywords. Searches were conducted on 2017 Dec 1-3. Papers were screened by title and abstract, and then selected for reviewing if it contained quantitative information about the contents of coumarins or safety issues of either C. verum or C. cassia. 


\section{Results and Discussions}

There are 3 most common ways to detect diabetic and prediabetic conditions: fasting blood glucose, HbA1c levels, and glucose tolerance (ADA, 2010; Patel and Macerollo, 2010). $\mathrm{HbA} 1 \mathrm{c}$ test is a blood test that provides the average blood glucose over the past 3 months. Oral Glucose Tolerance Test (OGTT) measures glucose tolerance by measuring blood glucose after fasting and after glucose intake. Trials reviewed in this study assessed the effectiveness of cinnamon in T2DM patients using these and related parameters, as well as the effect of $C$. cassia and $C$. verum on related conditions and healthy populations.

\subsection{Cinnamon for diabetes management}

A total of 12 database searches (4 for each database: PubMed, ScienceDirect, and Cochrane Library) were conducted using the 4 search terms, and 308 results were obtained. There were 67 results (39 from PubMed, 21 from ScienceDirect, and 7 from Cochrane Library) for 'Cinnamomum verum, 121 results (38 from PubMed, 37 from ScienceDirect, and 46 from Cochrane Library) for 'Cinnamomum zeylanicum', 100 results (10 from PubMed, 78 from ScienceDirect, and 12 from Cochrane Library) for 'Cinnamomum cassia', and 20 results ( 7 from PubMed, 6 from ScienceDirect, and 7 from Cochrane Library) for 'Cinnamomum aromaticum'. After removing duplicates and screening from title and abstract, 32 articles remained. Seven studies were removed, three due to the lack of information on the cinnamon species used in the trials (Altschuler et al., 2007; Khan et al., 2010; Mirfeizi et al., 2016); three using a different species: C.burmanii as the formulation CinSulin (Anderson et al., 2016; Roussel et al., 2009; Ziegenfuss et al., 2006); one using a combination product including zinc gluconate (Wainstein et al., 2011). The remaining 25 studies of 997 participants were selected for reviewing (Table 1). The selection process is presented in a flowchart (Figure 1).

Fifteen studies were conducted on T2DM patients, among which twelve trials used $C$. cassia (Akilen et al., 2010; Blevins et al., 2007; Crawford, 2009; Gullapalli et al., 2013; 
Hasanzade et al., 2013; Khan et al., 2003; Lu et al., 2012; Mang et al., 2006; Sengsuk et al., 2016; Soni and Bhatnagar, 2009; Suppapitiporn et al., 2006; Vanschoonbeek et al., 2006) (n=730) and three trials used $C$. verum (Azimi et al., 2014; Azimi et al., 2016; Vafa et al., 2012) $(\mathrm{n}=123)$. Dosages were 1-3g per day, and durations of the trials ranged from 30 days to four months. Reduction in fasting blood glucose or other diabetes-related parameters were demonstrated in ten studies (C. cassia $1.5-6 \mathrm{~g}$ per day for 40 days - four months, or $C$. verum 3g per day for 8 weeks) (Akilen et al., 2010; Azimi et al., 2014; Azimi et al., 2016; Crawford, 2009; Gullapalli et al., 2013; Khan et al., 2003; Lu et al., 2012; Mang et al., 2006; Sengsuk et al., 2016; Soni and Bhatnagar, 2009), and a study showed postprandial blood glucose decrease after 40-day administration of C. cassia (2g per day) (Soni and Bhatnagar, 2009). On the other hand, four studies found no significant effect on fasting blood glucose levels after 1-1.5g C. cassia administration for 30 days - three months (Blevins et al., 2007; Hasanzade et al., 2013; Suppapitiporn et al., 2006; Vanschoonbeek et al., 2006). Four studies $(n=82)$ were conducted on subjects with other clinical conditions such as impaired glucose tolerance (IGT), high fasting or postload blood glucose levels and obesity. Among these studies, three trials used C. cassia (Gutierrez et al., 2016; Magistrelli and Chezem, 2012; Wickenberg et al., 2014) (n=72) and one trial used C. verum (Wickenberg et al., 2012) $(n=10)$. Three trials were conducted on postprandial glucose levels using an oral glucose tolerance test with cinnamon intake at the test (Gutierrez et al., 2016; Wickenberg et al., 2012; Magistrelli and Chezem, 2012). Intake of C. cassia 5-6g reduced postprandial glucose levels in obese individuals (Gutierrez et al., 2016; Magistrelli and Chezem, 2012), while $C$. verum $6 \mathrm{~g}$ had no effect in IGT patients (Wickenberg et al., 2012). Twelve-week oral administration of $12 \mathrm{~g}$ of $C$. cassia had no effect on insulin sensitivity, fasting blood glucose or HbA1c (Wickenberg et al., 2014). Six studies were conducted on 84 healthy subjects, among which four trials used C. cassia (Hlebowicz et al., 2009; Mettler et al., 2009; Solomon and Blannin, 2007, 2009) and two trials used C. verum (Beejmohun et al., 2014; Markey et al., 2011). Five OGTT studies were conducted with C. cassia or C. verum (Beejmohun et al., 2014; Hlebowicz et al., 2009; Markey et al., 2011; Mettler et al., 2009; Solomon and Blannin, 
2007) and one study looked at postprandial glucose and insulin levels after 14-day administration of C. cassia (Solomon and Blannin, 2009). Positive outcomes were obtained in the trials using C. cassia (3-5g) (Hlebowicz et al., 2009; Mettler et al., 2009; Solomon and Blannin, 2007, 2009), and $1 \mathrm{~g}$ alcoholic extract of C. verum (Beejmohun et al., 2014). However, C. verum $3 \mathrm{~g}$ had no effect on postprandial glucose and lipid levels after a high fat meal (Markey et al., 2011).

\subsubsection{T2DM: C. cassia and C. verum compared (Table 2-1)}

Out of 15 studies on T2DM patients, 12 used C. cassia and three used C. verum. Of these 15 studies, ten reported significant improvements with a variety of outcome measures including HbA1c, fasting blood glucose, postprandial blood glucose and insulin as well as the pathometabolically related parameters of blood pressure. Eight of these ten positive outcomes were from the 12 C. cassia studies (Akilen et al., 2010; Blevins et al., 2007; Crawford, 2009; Gullapalli et al., 2013; Hasanzade et al., 2013; Khan et al., 2003; Lu et al., 2012; Mang et al., 2006; Sengsuk et al., 2016; Soni and Bhatnagar, 2009; Suppapitiporn et al., 2006;

Vanschoonbeek et al., 2006) and the remaining positive outcomes were two of the three $C$. verum studies (Azimi et al., 2014; Vafa et al., 2012). Furthermore, C. cassia 1.5-6g per day, aqueous extract $120-360 \mathrm{mg}$ per day for 40 days - three months, or C. verum $3 \mathrm{~g}$ per day for eight weeks reduced triglyceride and LDL levels in T2DM patients (Khan et al., 2003; Lu et al., 2012; Sengsuk et al., 2016). Considering that body fat is a significant diabetes-associated risk factor for cardiovascular disease (Howard et al., 2000), C. cassia and C. verum may help prevent the development of vascular comorbidity in T2DM. Five studies (Azimi et al., 2016; Blevins et al., 2007; Hasanzade et al., 2013; Suppapitiporn et al., 2006; Vanschoonbeek et al., 2006) reported no improvements in the analysed outcome measures including fasting glucose levels and HbA1c. Four of these were $C$. cassia studies (Blevins et al., 2007; Hasanzade et al., 2013; Suppapitiporn et al., 2006; Vanschoonbeek et al., 2006) and one was a C. verum study (Azimi et al., 2016). The dosages for three of $C$. cassia studies were $1 \mathrm{~g}$ per day (Blevins et al., 2007; Hasanzade et al., 2013), and 1.5g per day (Suppapitiporn et al., 2006; 
Vanschoonbeek et al., 2006). These dosages are low compared to the most commonly used dosage of $3 \mathrm{~g}$ per day. In addition, the duration in the Hasanzade study was 30 days

(Hasanzade et al., 2013), which is likely too short to meaningfully assess changes in HbA1c levels, an outcome measure used in the study. Administration of $3 \mathrm{~g}$ per day for eight weeks showed no improvement in a study (Azimi et al., 2016), which measured blood pressure and endothelial function in T2DM rather than direct blood glucose parameters. This is relevant considering the relationship between poor blood glucose control and hypertension via the development of atherosclerosis may take longer to modify than eight weeks that was provided in the trial. Interestingly, when the same authors reported fasting blood glucose as the outcome measure on this study, a decrease was found (Azimi et al., 2014), suggesting it is easier to modify this parameter with $C$. verum than its downstream effects. Both publications (Azimi et al., 2014; Azimi et al., 2016) refer to different datasets within the same study of four individual herbal interventions, including C. verum $3 \mathrm{~g} / \mathrm{day}$.

\subsubsection{Related Clinical Conditions: $C$. cassia and $C$. verum compared (Table 2-2)}

Four studies were conducted on subjects with clinical conditions other than T2DM:

IGT (Wickenberg et al., 2012; Wickenberg et al., 2014) as a pre-diabetic condition, and obesity (Gutierrez et al., 2016; Magistrelli and Chezem, 2012), which is a risk factor for diabetes. In obese subjects, ingestion of $C$. cassia $5 \mathrm{~g}$ and $6 \mathrm{~g}$ suppressed postprandial glucose rise (Gutierrez et al., 2016; Magistrelli and Chezem, 2012).. In a study with IGT participants, Wickenberg et al. found no impact of $C$. cassia $12 \mathrm{~g}$ per day for 12 weeks on the fasting glucose and insulin levels (Wickenberg et al., 2014). These findings suggest the potential effectiveness of C. cassia at $5 \mathrm{~g}-6 \mathrm{~g}$ per day, but not as high as $12 \mathrm{~g}$ per day for the prevention of T2DM development in individuals with high risk.

Turning to C. verum, Wickenberg also authored a study on C. verum, and found no effect of C. verum $6 \mathrm{~g}$ on postprandial blood glucose and insulin levels (Wickenberg et al., 2012). 


\subsubsection{Healthy: $C$. cassia and $C$. verum compared (Table 2-3)}

A study on healthy subjects found that postprandial insulin rise was suppressed by $3 \mathrm{~g} C$. cassia but not by $1 \mathrm{~g}$ (Hlebowicz et al., 2009), suggesting that the critical dosage of C. cassia lies between 1 and $3 \mathrm{~g}$ per day. Single administration of $C$. cassia $(3 \mathrm{~g}$ or $5 \mathrm{~g}$ ) (Hlebowicz et al., 2009; Solomon and Blannin, 2007) and C. cassia (3g) for 14 days (Solomon and Blannin, 2009) led to decrease in postprandial glucose response. Mettler et al. reported that $C$. cassia $4 \mathrm{~g}$ had a significant impact on postprandial glucose levels only when taken in combination with acetic acid (Mettler et al., 2009). Interestingly, in the historical text 'Le Livre des Simples Medecines', combination of cinnamon with vinegar is suggested for its effectiveness (Nam, 2014). These data suggest that $C$. cassia powder $3 \mathrm{~g}$ or $C$. cassia taken with vinegar, could help control blood glucose levels and associated parameters, which may be of benefit to T2DM patients.

In two C. verum studies in healthy populations, ingestion of an alcoholic extract (1g) of $C$. verum led to a reduction in postprandial glucose and insulin levels (Beejmohun et al., 2014), while ingestion of a dose of $C$. verum $3 \mathrm{~g}$ with a high fat meal (Markey et al., 2011) did not influence postprandial changes in glucose and triacylglycerol levels.

Overall, $C$. cassia $(\geq 3 \mathrm{~g})$ in healthy individuals had positive outcomes in postprandial glucose control, while evidence supporting $C$. verum is insufficient.

\subsection{Safety issues}

\subsubsection{Adverse events in the clinical trials}

Ten studies positively reported no adverse events. Fourteen studies did not report whether or not any adverse events occurred during the studies. One study reported a subject developing a rash (Crawford, 2009). Another study (Wickenberg et al., 2014), using 12g/day C .cassia for 12 weeks, whilst not actively reporting adverse events, did measure liver enzymes, and found no change in serum transaminases. 
Due to the high coumarin content of $C$. cassia, $C$. verum has been suggested to be a safe alternative intervention for diabetes (Medagama, 2015). Coumarin ( $2 H$-chromen-2-one) is a naturally occurring constituent of many plants, and long term use of cinnamon as a flavouring agent is generally considered safe (Leach and Kumar, 2012). It was first isolated from tonga beans Dipteryx odorata (Aubl.) Willd. in 1820 and chemically synthesized coumarin had been marketed as a food flavouring agent for a long time until its hepatotoxic potential was discovered in laboratory animals in the middle of the $20^{\text {th }}$ century. From the $1970 \mathrm{~s}$, coumarin was approved as a medicine to treat oedemas as well as tumours in several countries.

However some patients developed severe hepatotoxicity, which led to the withdrawal of products from the market in 1990s (Abraham et al., 2010). Coumarin is metabolized via two major pathways: detoxification by 7-hydroxylation and the formation of 3,4-epoxide intermediate, the latter of which leads to the generation of a hepatotoxic metabolite $o$-HPA. As the 7-hydroxyation pathway is predominant in primates including humans, humans are less susceptible to coumarin hepatotoxicity compared to rodents. However, clinical data revealed that a human population subgroup reacts sensitively to coumarin (Loprinzi et al., 1999; Schmeck-Lindenau et al., 2003), although the underlying mechanism is unknown (Abraham et al., 2010).

To evaluate the coumarin-related safety issues of the two cinnamon species, database searches were conducted. The search retrieved a total of 19 results (18 results for PubMed, 1 for ScienceDirect), of which five articles are selected and summarised in Table 3. Abraham et al. (2011) compared the absorption of coumarin after oral administration of isolated coumarin and C. cassia in different preparations (capsules, tea, and rice pudding) (Abraham et al., 2011). They found that coumarin in isolation and in C. cassia were equally absorbed, and that C. cassia tea exhibited the fastest and highest coumarin absorption, compared to capsules and rice pudding. Data on the coumarin contents in different cinnamon species confirmed higher coumarin levels in C. cassia compared to C. verum (Table 3). Three independent studies conducted on the coumarin levels of $C$. cassia reported considerably different values: $2.57 \pm 0.08 \mathrm{~g} / \mathrm{kg}(2.512-2.628 \mathrm{~g} / \mathrm{kg})$ (Krieger et al., 2013), $0.201 \pm 0.104 \mathrm{~g} / \mathrm{kg}(0.085-0.310 \mathrm{~g} / \mathrm{kg})$ 
(Wang et al., 2013), and 1.60 $\pm 1.70 \mathrm{~g} / \mathrm{kg}(0.33-6.5 \mathrm{~g} / \mathrm{kg})$ ( $\mathrm{Lv}$ et al., 2010), which could be due to several factors including extraction methods, analytical methods, and the sources of plant materials. In fact, those studies were conducted using different extraction and analytical methods, namely $80 \%$ methanol extraction without heat or sonication and LC-MS and DIPAPCI-MS analyses (Krieger et al., 2013), methanol extraction with sonication and UPLCUV/MS (Wang et al., 2013), and pressurized liquid extraction with ethyl acetate at $160^{\circ} \mathrm{C}$ and and GC-MS (Lv et al., 2010), which could underlie the variability in these studies. Furthermore, plant materials were obtained from different sources, such as German retail market (Krieger et al., 2013), commercial source in China and the United States (Wang et al., 2013), and different regions of China (Lv et al., 2010). As demonstrated by Lv et al., coumarin contents of $C$. cassia could considerably vary (from 0.33 to $6.50 \mathrm{mg} / \mathrm{g}$ ) depending on the geographical origins (Lv et al., 2010), which is likely due to different climatic conditions, plant age, and harvest timings. In addition, coumarin levels could vary depending on which plant parts were used. A study compared the levels of coumarin and other constituents in the bark, shaved bark (without cork layer), and twig of C. cassia, both used in traditional East Asian medicines, and found that coumarin in cinnamon twig was less than one-third compared to cinnamon bark, and shaved cinmmamon bark contained the highest levels of coumarin (Chen et al., 2016). Importantly, a study showed that a de-coumarinated polyphenol-enriched C. cassia extract, prepared using a novel procedure, was effective in lowering blood glucose levels in T2DM rats (IM et al., 2014a), indicating that the selection of extraction procedure could significantly enhance the safety of $C$. cassia. Of note, $C$. burmannii (Nees \& T. Nees) Blume, commonly also known as 'cassia' cinnamon (Avula et al., 2015), has characteristically high coumarin levels, which is distinct from C. cassia (Avula et al., 2015; Chen et al., 2014; Wang et al., 2013), and C. burmannii was likely referred to as 'cassia' cinnamon in some reports. Importantly, Wang et al. reported that $C$. cassia contains higher levels of cinnamaldehyde: C. cassia $(18.5 \pm 2.9 \mathrm{~g} / \mathrm{kg}, \mathrm{n}=4)>$ C. verum $(11.2 \pm 5.5 \mathrm{~g} / \mathrm{kg}$, $\mathrm{n}=17$ ) (Wang et al., 2013). Considering that anti-diabetic actions of cinnamon is at least partly mediated by cinnamaldehyde ( $\mathrm{Li}$ et al., 2012), the dosage of $C$. verum should be carefully 
considered as a replacement for $C$. cassia. In fact, short-term administration ( $\leq 14$ days) of $C$. verum (3g and 6g) were ineffective (Markey et al., 2011; Wickenberg et al., 2012), while $C$. cassia 3 - 6 g were effective (Hlebowicz et al., 2009; Magistrelli and Chezem, 2012; Mettler et al., 2009; Solomon and Blannin, 2007), suggesting that C. cassia has higher potency compared to C. verum. Overall, it is important to identify botanical origin, geographical origin, plant parts, and extraction procedures, in using and reporting analytical as well as clinical trial data.

In addition to liver damage caused by coumarin, allergic reactions should be considered as a possible adverse effect, as several cases of contact dermatitis have been reported (Ackermann et al., 2009; Calapai et al., 2014; Isaac-Renton et al., 2015). In fact, a subject developed a rash after consuming C. cassia 1g per day in a trial (Crawford, 2009), however this was the only adverse reaction reported in any of the trials considered in this review. In fact, no case reports of interactions were identified therefore it was considered unlikely that it would affect the effectiveness of conventional drugs (Edwards et al., 2015). However, pharmacovigilance is important for any potential interactions and additive effects. Both $C$. verum and C. cassia, in therapeutic doses, should be avoided during pregnancy (Edwards et al., 2015; Gardner and McGuffin, 2013).

\subsection{Limitation of the study}

Due to the scarcity of available data, this study included both randomised placebo-controlled and open-label trials. In addition, compared to C. cassia, only a few trials have been conducted with C. verum. This is limiting as the discussion is based on evidence supported by a small number of studies with less vigorous study designs. More robust studies are needed in the future.

3.4 Concluding remarks 
Most clinical studies were conducted using $C$. cassia, which was originally used as an antidiabetic medicine and listed as the unique origin of 'Cortex cinnamomi' in the Chinese pharmacopoeia (Lv et al., 2010). Evidence suggests that oral administration of C. cassia 3-6g per day could improve glucose metabolism in T2DM patients and healthy individuals, while effectiveness was inconsistent below 1.5g. However, heterogeneity in the methods used in the trials as well as quality issues including lack of botanical authentication compromise the evidence for the efficacy and safety.

Therapeutic potency depends on the levels of active constituents. Considering that medicinal plants in general contain a number of bioactive compounds, the levels of which could be affected by many factors such as geographical origin, plant parts, and crude drug processing, it is important to assess the chemical properties of botanical medicines before using and evaluating the therapeutic potency and safety. In addition, due to the high coumarin content of $C$. cassia, future trials should be designed taking into account the assessment of potential hepatotoxicity by including liver function tests over suitable trial durations. These efforts would allow a more reliable safety and efficacy evaluation of $C$. cassia. as a diabetes intervention.

On the other hand, data are scarce and inconclusive for the effectiveness of $C$. verum. It should be noted that the interchangeability of the two cinnamon species as a diabetes intervention is not established and there is currently no standardisation method for quality control. It is important for practitioners to consider possible differences in the potency between the two species as well as within the same species, and potential risk associated with coumarin consumption. Given the low coumarin content of $C$. verum there is an opportunity for more robust RCTs, of longer duration and larger participant numbers giving greater power, to investigate whether this species has potential for this growing patient group. The effective and safe dosage practices for different species should be built on scientific data through careful examination and comparison, as well as drawing on long-standing traditional usages. Key to this is clarity about the intervention including establishing botanical authenticity. Such work could not only benefit T2DM patients and those diagnosed as pre- 
diabetic, but also the growing number of diseases that are related to insulin resistance, and hence favourably ameliorate the personal, social and economic costs of these conditions.

\section{Conflict of Interest}

The authors declare no conflicts of interest associated with this manuscript.

\section{Financial support}

There is no financial support for this manuscript. 


\section{References}

Abraham, K., Pfister, M., Wöhrlin, F., Lampen, A., 2011. Relative bioavailability of coumarin from cinnamon and cinnamon-containing foods compared to isolated coumarin: a four-way crossover study in human volunteers. Mol Nutr Food Res. 55(4), 644-653.

Abraham, K., Wöhrlin, F., Lindtner, O., Heinemeyer, G., Lampen, A., 2010. Toxicology and risk assessment of coumarin: focus on human data. Mol Nutr Food Res. 54(2), 228-239.

Ackermann, L., Aalto-Korte, K., Jolanki, R., Alanko, K., 2009. Occupational allergic contact dermatitis from cinnamon including one case from airborne exposure. Contact Dermatitis 60(2), 96-99.

ADA, 2010. Diagnosis and Classification of Diabetes Mellitus. Diabetes Care 33(Suppl 1), S62-S69.

ADA, 2013. Economic costs of diabetes in the U.S. in 2012. Diabetes Care 36(4), 1033-1046.

Akilen, R., Tsiami, A., Devendra, D., Robinson, N., 2010. Glycated haemoglobin and blood pressure-lowering effect of cinnamon in multi-ethnic Type 2 diabetic patients in the UK: a randomized, placebo-controlled, double-blind clinical trial. Diabet Med. 27(10), 1159-1167.

Akilen, R., Tsiami, A., Devendra, D., Robinson, N., 2012. Cinnamon in glycaemic control: Systematic review and meta analysis. Clin Nutr. 31(5), 609-615.

Alanazi, A.S., Khan, M.U., 2015. CINNAMON USE IN TYPE 2 DIABETES: AN UPDATED META-ANALYSIS. World Journal of Pharmacy and Pharmaceutical Sciences $4(5), 1838-1852$.

Allen, R.W., Schwartzman, E., Baker, W.L., Coleman, C.I., Phung, O.J., 2013. Cinnamon use in type 2 diabetes: an updated systematic review and meta-analysis. Ann Fam Med. 11(5), 452-459.

Altschuler, J.A., Casella, S.J., MacKenzie, T.A., Curtis, K.M., 2007. The effect of cinnamon on A1C among adolescents with type 1 diabetes. Diabetes Care 30(4), 813-816.

Anderson, R.A., Broadhurst, C.L., Polansky, M.M., Schmidt, W.F., Khan, A., Flanagan, V.P., Schoene, N.W., Graves, D.J., 2004. Isolation and characterization of polyphenol type-A polymers from cinnamon with insulin-like biological activity. J Agric Food Chem. 52(1), 6570.

Anderson, R.A., Zhan, Z., Luo, R., Guo, X., Guo, Q., Zhou, J., Kong, J., Davis, P.A., Stoecker, B.J., 2016. Cinnamon extract lowers glucose, insulin and cholesterol in people with elevated serum glucose. J Tradit Complement Med. 6(4), 332-336.

Avula, B., Smillie, T.J., Wang, Y.H., Zweigenbaum, J., Khan, I.A., 2015. Authentication of true cinnamon (Cinnamon verum) utilising direct analysis in real time (DART)-QToF-MS. Food Addit Contam Part A Chem Anal Control Expo Risk Assess. 32(1), 1-8.

Azimi, P., Ghiasvand, R., Feizi, A., Hariri, M., B., A., 2014. Effects of Cinnamon, Cardamom, Saffron, and Ginger Consumption on Markers of Glycemic Control, Lipid Profile, Oxidative Stress, and Inflammation in Type 2 Diabetes Patients. Rev Diabet Stud. 11(3-4), 258-266. 
Azimi, P., Ghiasvand, R., Feizi, A., Hosseinzadeh, J., Bahreynian, M., Hariri, M., KhosraviBoroujeni, H., 2016. Effect of cinnamon, cardamom, saffron and ginger consumption on blood pressure and a marker of endothelial function in patients with type 2 diabetes mellitus: A randomized controlled clinical trial. Blood Press. 25(3), 133-140.

Ballestri, S., Zona, S., Targher, G., Romagnoli, D., Baldelli, E., Nascimbeni, F., Roverato, A., Guaraldi, G., Lonardo, A., 2016. Nonalcoholic fatty liver disease is associated with an almost twofold increased risk of incident type 2 diabetes and metabolic syndrome. Evidence from a systematic review and meta-analysis. J Gastroenterol Hepatol. 31(5), 936-944.

Beejmohun, V., Peytavy-Izard, M., Mignon, C., Muscente-Paque, D., Deplanque, X., Ripoll, C., Chapal, N., 2014. Acute effect of Ceylon cinnamon extract on postprandial glycemia: alpha-amylase inhibition, starch tolerance test in rats, and randomized crossover clinical trial in healthy volunteers. BMC Complement Altern Med. 14, 351.

Blevins, S.M., Leyva, M.J., Brown, J., Wright, J., Scofield, R.H., Aston, C., 2007. Effect of cinnamon on glucose and lipid levels in non insulin-dependent type 2 diabetes. Diabetes Care 30(9), 2236-2237.

Bone, K, and S Mills. 2013. Principles and Practice of Phytotherapy: Modern Herbal Medicine. 2nd ed. Edinburgh, London, New York, Oxford, Philadelphia, St Louis, Sydney, Toronto: Churchill Livingstone.

Calapai, G., Miroddi, M., Mannucci, C., Minciullo, P., Gangemi, S., 2014. Oral adverse reactions due to cinnamon-flavoured chewing gums consumption. Oral Dis. 20(7), 637-643.

Cao, H., Urban, J.F.J., Anderson, R.A., 2008. Cinnamon polyphenol extract affects immune responses by regulating anti- and proinflammatory and glucose transporter gene expression in mouse macrophages. J Nutr. 138(5), 833-840.

Chen, L., Sun, P., Wang, T., Chen, K., Jia, Q., Wang, H., Li, Y., 2012. Diverse mechanisms of antidiabetic effects of the different procyanidin oligomer types of two different cinnamon species on db/db mice. J Agric Food Chem. 60(36), 9144-9150.

Chen, P., Sun, J., Ford, P., 2014. Differentiation of the four major species of cinnamons (C. burmannii, C. verum, C. cassia, and C. loureiroi) using a flow injection mass spectrometric (FIMS) fingerprinting method. J Agric Food Chem. 62(12), 2516-2521.

Chen, P.Y., Yu, J.W., Lu, F.L., Lin, M.C., Cheng, H.F., 2016. Differentiating parts of Cinnamomum cassia using LC-qTOF-MS in conjunction with principal component analysis. Biomed Chromatogr. 30(9), 1449-1457.

Crawford, P., 2009. Effectiveness of cinnamon for lowering hemoglobin A1C in patients with type 2 diabetes: a randomized, controlled trial. J Am Board Fam Med. 22(5), 507-512.

De Vos, P., 2010. European materia medica in historical texts: longevity of a tradition and implications for future use. J Ethnopharmacol. 132(1), 28-47.

Edwards, S.E., da Costa Rocha, I., Williamson, E.M., Heinrich, M., 2015. Phytopharmacy: An Evidence-Based Guide to Herbal Medicinal Products. WILEY.

EMA, 2011a. Assessment report on Cinnamomum verum J. S. Presl, cortex and corticis aetheroleum (EMA/HMPC/246773/2009). EMA committee on Herbal Medicinal Products. 
EMA, 2011b. Community herbal monograph on Cinnamum verum J.S. Presl, cortex (EMA/HMPC/246774/2009). EMA committee on Herbal Medicinal Products

Fong, H.H., 2002. Integration of herbal medicine into modern medical practices: issues and prospects. Integr Cancer Ther. 1(3), 287-293.

Gagnier, J.J., Boon, H., Rochon, P., Moher, D., Barnes, J., Bombardier, C., Group, C., 2006. Reporting randomized, controlled trials of herbal interventions: an elaborated CONSORT statement. Ann Intern Med. 144(5), 364-367.

Gardner, Z., McGuffin, M., 2013. Amedican Herbal Product Association's BOtanical Safety Handbook. 2nd Edition, USA.

Gudala, K., Bansal, D., Schifano, F., Bhansali, A., 2013. Diabetes mellitus and risk of dementia: A meta-analysis of prospective observational studies. J Diabetes Investig. 4(6), 640-650.

Gullapalli, H.S., Avinash, P.T., Gullapalli, N.H., 2013. Effects of Consumption of Cinnamon on Blood Glucose and Lipid profile of the Patients of Type 2 Diabetes. Sch. J. App. Med. Sci. $1(2), 28-32$.

Gutierrez, J.L., Bowden, R.G., Willoughby, D.S., 2016. Cassia Cinnamon Supplementation Reduces Peak Blood Glucose Responses but Does Not Improve Insulin Resistance and Sensitivity in Young, Sedentary, Obese Women. J Diet Suppl. 13(4), 461-471.

Hasanzade, F., Toliat, M., Emami, S.A., Emamimoghaadam, Z., 2013. The Effect of Cinnamon on Glucose of Type II Diabetes Patients. J Tradit Complement Med. 3(3), 171174.

Hlebowicz, J., Hlebowicz, A., Lindstedt, S., Björgell, O., Höglund, P., Holst, J.J., Darwiche, G., Almér, L.O., 2009. Effects of 1 and $3 \mathrm{~g}$ cinnamon on gastric emptying, satiety, and postprandial blood glucose, insulin, glucose-dependent insulinotropic polypeptide, glucagonlike peptide 1, and ghrelin concentrations in healthy subjects. Am J Clin Nutr. 89(3), 815-821.

Honors, M.A., Kinzig, K.P., 2012. The role of insulin resistance in the development of muscle wasting during cancer cachexia. . J Cachexia Sarcopenia Muscle 3(1), 5-11.

Howard, B.V., Robbins, D.C., Sievers, M.L., Lee, E.T., Rhoades, D., Devereux, R.B., Cowan, L.D., Gray, R.S., Welty, T.K., Go, O.T., Howard, W.J., 2000. LDL cholesterol as a strong predictor of coronary heart disease in diabetic individuals with insulin resistance and low LDL: The Strong Heart Study. Arterioscler Thromb Vasc Biol. 20(3), 830-835.

IM, K., Issac, A., Ninan, E., Kuttan, R., Maliakel, B., 2014a. Enhanced anti-diabetic activity of polyphenol-rich de-coumarinated extracts of Cinnamomum cassia. J Funct Foods 10(54$64)$.

IM, K., Issac, A., NM, J., Ninan, E., Maliakel, B., Kuttan, R., 2014b. Effect of polyphenol content upon the anti-diabetic activity of Cinnamomum zeylanicum extracts. Food Funct. 5(9), 2208-2220.

Isaac-Renton, M., Li, M.K., Parsons, L.M., 2015. Cinnamon spice and everything not nice: many features of intraoral allergy to cinnamic aldehyde. Dermatitis 26(3), 116-121.

Jönsson B, Board., C.-A., 2002. Revealing the cost of Type II diabetes in Europe.

Diabetologia 45(7), S5-12. 
Kadan, S., Saad, B., Sasson, Y., Zaid, H., 2013. Evid Based Complement Alternat Med. In Vitro Evaluations of Cytotoxicity of Eight Antidiabetic Medicinal Plants and Their Effect on GLUT4 Translocation 2013, 549345.

Kahn, S.E., Hull, R.L., Utzschneider, K.M., 2006. Mechanisms linking obesity to insulin resistance and type 2 diabetes. Nature 444(7121), 840-846.

Kaul, P.N., Bhattacharya, A.K., Rao, B.R.R., Syamasundar, K.V., Ramesh, S., 2003. Volatile constituents of essential oils isolated from different parts of cinnamon (Cinnamomum zeylanicum Blume). J Sci Food Agric. 83(1), 53-55.

Khan, A., Safdar, M., Ali Khan, M.M., Khattak, K.N., Anderson, R.A., 2003. Cinnamon improves glucose and lipids of people with type 2 diabetes. Diabetes Care 26(12), 3215-3218. Khan, R., Khan, Z., Shah, S.H., 2010. Cinnamon may reduce glucose, lipid and cholesterol level in type 2 diabetic individuals. Pakistan Journal of Nutrition 9(5), 430-433.

Kim, S.H., Hyun, S.H., Choung, S.Y., 2006. Anti-diabetic effect of cinnamon extract on blood glucose in db/db mice. J Ethnopharmacol. 104(1-2), 119-123.

Klein, S, and R Rister. 1998. The Complete German Commission E Monographs: Therapeutic Guide to Herbal Medicine (English Translation). Edited by M Blumenthal. Austin, TX: American Botanical Council.

Köster, I., von Ferber, L., Ihle, P., Schubert, I., Hauner, H., 2006. The cost burden of diabetes mellitus: the evidence from Germany - the CoDiM Study. Diabetologia 49(7), 1498-1504.

Krieger, S., Hayen, H., Schmitz, O.J., 2013. Quantification of coumarin in cinnamon and woodruff beverages using DIP-APCI-MS and LC-MS. Anal Bioanal Chem. 405(25), 83378345 .

Leach, M.J., Kumar, S., 2012. Cinnamon for diabetes mellitus. Cochrane Database Syst Rev. 9, CD007170.

Li, J., Liu, T., Wang, L., Guo, X., Xu, T., Wu, L., Qin, L., Sun, W., 2012. Antihyperglycemic and antihyperlipidemic action of cinnamaldehyde in C57BLKS/J db/db mice. J Tradit Chin Med. 32(2), 446-452.

Loprinzi, C.L., Kugler, J.W., Sloan, J.A., Rooke, T.W., Quella, S.K., Novotny, P., Mowat, R.B., Michalak, J.C., Stella, P.J., Levitt, R., Tschetter, L.K., Windschitl, H., 1999. Lack of Effect of Coumarin in Women with Lymphedema after Treatment for Breast Cancer. N Engl J Med. 340, 346-350.

Lu, T., Sheng, H., Wu, J., Cheng, Y., Zhu, J., Chen, Y., 2012. Cinnamon extract improves fasting blood glucose and glycosylated hemoglobin level in Chinese patients with type 2 diabetes. Nutr Res. 23(6), 408-412.

Lv, G.P., Huang, W.H., Yang, F.Q., Li, J., Li, S.P., 2010. Pressurized liquid extraction and GC-MS analysis for simultaneous determination of seven components in Cinnamomum cassia and the effect of sample preparation. J Sep Sci. 33(15), 2341-2348.

Magistrelli, A., Chezem, J.C., 2012. Effect of ground cinnamon on postprandial blood glucose concentration in normal-weight and obese adults. J Acad Nutr Diet. 112(11), 18061809. 
Malaguarnera, R., Vella, V., Nicolosi, M.L., Belfiore, A., 2017. Insulin Resistance: Any Role in the Changing Epidemiology of Thyroid Cancer? Front Endocrinol (Lausanne). 8, 314.

Mang, B., Wolters, M., Schmitt, B., Kelb, K., Lichtinghagen, R., Stichtenoth, D.O., Hahn, A., 2006. Effects of a cinnamon extract on plasma glucose, $\mathrm{HbA}$, and serum lipids in diabetes mellitus type 2. Eur J Clin Invest. 36(5), 340-344.

Mannucci, E., Dicembrini, I., Lauria, A., Pozzilli, P., 2013. Is glucose control important for prevention of cardiovascular disease in diabetes? Diabetes Care. 36(Suppl 2), S259-263.

Markey, O., McClean, C.M., Medlow, P., Davison, G.W., Trinick, T.R., Duly, E., Shafat, A., 2011. Effect of cinnamon on gastric emptying, arterial stiffness, postprandial lipemia, glycemia, and appetite responses to high-fat breakfast. Cardiovasc Diabetol. 10, 78.

Matsuzaki, T., Sasaki, K., Tanizaki, Y., Hata, J., Fujimi, K., Matsui, Y., Sekita, A., Suzuki, S.O., Kanba, S., Kiyohara, Y., Iwaki, T., 2010. Insulin resistance is associated with the pathology of Alzheimer disease: the Hisayama study. Neurology 75(9), 764-770.

Medagama, A.B., 2015. The glycaemic outcomes of Cinnamon, a review of the experimental evidence and clinical trials. Nutr J. 14(1), 108.

Mettler, S., Schwarz, I., Colombani, P.C., 2009. Additive postprandial blood glucoseattenuating and satiety-enhancing effect of cinnamon and acetic acid. Nutr Res. 29(10), 723 727.

Mirfeizi, M., Mehdizadeh Tourzani, Z., Mirfeizi, S.Z., Asghari Jafarabadi, M., Rezvani, H.R., Afzali, M., 2016. Controlling type 2 diabetes mellitus with herbal medicines: A triple-blind randomized clinical trial of efficacy and safety. J Diabetes. 8(5), 647-656.

Nabavi, S.F., Di Lorenzo, A., Izadi, M., Sobarzo-Sánchez, E., Daglia, M., Nabavi, S.M., 2015. Antibacterial Effects of Cinnamon: From Farm to Food, Cosmetic and Pharmaceutical Industries. Nutrients 7(9), 7729-7748.

Nam, J.K., 2014. Medieval European medicine and Asian spices. Uisahak 23(2), 319-342.

Ninomiya, T., 2014. Diabetes mellitus and dementia. Curr Diab Rep. 14(5), 487.

Ojo, O., Brooke, J., 2015. Evaluating the Association between Diabetes, Cognitive Decline and Dementia. Int J Environ Res Public Health 12(7), 8281-8294.

Patel, P., Macerollo, A., 2010. Diabetes mellitus: diagnosis and screening. Am Fam Physician 81(7), 863-870.

Pauli, J.M., Raja-Khan, N., Wu, X., Legro, R.S., 2011. Current perspectives of insulin resistance and polycystic ovary syndrome. Diabet Med. 28(12), 1445-1454.

Posadzki, P., Watson, L., Ernst, E., 2012. Contamination and adulteration of herbal medicinal products (HMPs): an overview of systematic reviews. Eur J Clin Pharmacol. 69(3), 295-307.

Rafehi, H., Ververis, K., Karagiannis, T.C., 2012. Controversies surrounding the clinical potential of cinnamon for the management of diabetes. Diabetes Obes Metab. 14(6), 493-499.

Ranasinghe, P., Pigera, S., Premakumara, G.A., Galappaththy, P., Constantine, G.R., Katulanda, P., 2013. Medicinal properties of 'true' cinnamon (Cinnamomum zeylanicum): a systematic review. BMC Complement Altern Med. 13. 
Rönnemaa, E., Zethelius, B., Sundelöf, J., Sundström, J., Degerman-Gunnarsson, M., Berne, C., Lannfelt, L., Kilander, L., 2008. Impaired insulin secretion increases the risk of Alzheimer disease. Neurology 71(14), 1065-1071.

Roussel, A.M., Hininger, I., Benaraba, R., Ziegenfuss, T.N., Anderson, R.A., 2009. Antioxidant effects of a cinnamon extract in people with impaired fasting glucose that are overweight or obese. J Am Coll Nutr. 28(1), 16-21.

Schmeck-Lindenau, H.J., Naser-Hijazi, B., Becker, E.W., Henneicke-von Zepelin, H.H., Schnitker, J., 2003. Safety aspects of a coumarin-troxerutin combination regarding liver function in a double-blind placebo-controlled study. Int J Clin Pharmacol Ther. 41(5), 193199.

Sengsuk, C., Sanguanwong, S., Tangvarasittichai, O., Tangvarasittichai, S., 2016. Effect of cinnamon supplementation on glucose, lipids levels, glomerular filtration rate, and blood pressure of subjects with type 2 diabetes mellitus. Diabetology International 7(2), 124-132.

Shamsi-Baghbanan, H., Sharifian, A., Esmaeili, S., Minaei, B., 2014. Hepatoprotective herbs, avicenna viewpoint. Iran Red Crescent Med J. 16(1), e12313.

Sheng, X., Zhang, Y., Gong, Z., Huang, C., Zang, Y.Q., 2008. Improved Insulin Resistance and Lipid Metabolism by Cinnamon Extract through Activation of Peroxisome ProliferatorActivated Receptors. PPAR Res. 2008, 581348.

Sola, D., Rossi, L., Schianca, G.P., Maffioli, P., Bigliocca, M., Mella, R., Corlianò, F., Fra, G.P., Bartoli, E., Derosa, G., 2015. Sulfonylureas and their use in clinical practice. Arch Med Sci. 11(4), 840-848.

Solomon, T.P., Blannin, A.K., 2007. Effects of short-term cinnamon ingestion on in vivo glucose tolerance. Diabetes Obes Metab. 9(6), 895-901.

Solomon, T.P., Blannin, A.K., 2009. Changes in glucose tolerance and insulin sensitivity following 2 weeks of daily cinnamon ingestion in healthy humans. Eur J Appl Physiol. 105(6), 969-976.

Soni, R., Bhatnagar, V., 2009. Effect of Cinnamon (Cinnamomum Cassia) intervention on Blood Glucose of Middle Aged Adult Male with Non Insulin Dependent Diabetes Mellitus (NIDDM). Ethno-Med 3(2), 141-144.

Struijs, J.N., Baan, C.A., Schellevis, F.G., Westert, G.P., van den Bos, G.A., 2006. Comorbidity in patients with diabetes mellitus: impact on medical health care utilization. BMC Health Serv Res. 6, 84.

Subash Babu, P., Prabuseenivasan, S., Ignacimuthu, S., 2007. Cinnamaldehyde--a potential antidiabetic agent. Phytomedicine 14(1), 15-22.

Suppapitiporn, S., Kanpaksi, N., Suppapitiporn, S., 2006. The effect of cinnamon cassia powder in type 2 diabetes mellitus. J Med Assoc Thai 89(Suppl 3), S200-205.

Vafa, M., Mohammadi, F., Shidfar, F., Sormaghi, M.S., Heidari, I., Golestan, B., Amiri, F., 2012. Effects of cinnamon consumption on glycemic status, lipid profile and body composition in type 2 diabetic patients. Int J Prev Med. 3(8), 531-536.

Vallverdú-Queralt, A., Regueiro, J., Martínez-Huélamo, M., Rinaldi Alvarenga, J.F., Leal, L.N., Lamuela-Raventos, R.M., 2014. A comprehensive study on the phenolic profile of 
widely used culinary herbs and spices: Rosemary, thyme, oregano, cinnamon, cumin and bay. Food Chemistry 154, 299-307.

van de Laar, F.A., 2008. Alpha-glucosidase inhibitors in the early treatment of type 2 diabetes. Vasc Health Risk Manag. 4(6), 1189-1195.

Vanschoonbeek, K., Thomassen, B.J., Senden, J.M., Wodzig, W.K., van Loon, L.J., 2006. Cinnamon supplementation does not improve glycemic control in postmenopausal type 2 diabetes patients. J Nutr. 136(4), 977-980.

Vona-Davis, L., Howard-McNatt, M., Rose, D.P., 2007. Adiposity, type 2 diabetes and the metabolic syndrome in breast cancer. Obes Rev. 8(5), 395-408.

Wainstein, J., Stern, N., Heller, S., Boaz, M., 2011. Dietary cinnamon supplementation and changes in systolic blood pressure in subjects with type 2 diabetes. J Med Food. 14(12), 15051510 .

Wang, Y.H., Avula, B., Nanayakkara, N.P., Zhao, J., Khan, I.A., 2013. Cassia cinnamon as a source of coumarin in cinnamon-flavored food and food supplements in the United States. J Agric Food Chem. 61(18), 4470-4476.

WHO, 2016. GLOBAL REPORT ON DIABETES. WHO/NMH/NVI/16.3.

Wickenberg, J., Lindstedt, S., Berntorp, K., Nilsson, J., Hlebowicz, J., 2012. Ceylon cinnamon does not affect postprandial plasma glucose or insulin in subjects with impaired glucose tolerance. Br J Nutr. 107(12), 1845-1849.

Wickenberg, J., Lindstedt, S., Nilsson, J., Hlebowicz, J., 2014. Cassia cinnamon does not change the insulin sensitivity or the liver enzymes in subjects with impaired glucose tolerance. Nutr J. 13(96).

Young, S.E., Mainous, A.G.r., Carnemolla, M., 2006. Hyperinsulinemia and cognitive decline in a middle-aged cohort. Diabetes Care. 29(12), 2688-2693.

Ziegenfuss, T.N., Hofheins, J.E., Mendel, R.W., Landis, J., Anderson, R.A., 2006. Effects of a water-soluble cinnamon extract on body composition and features of the metabolic syndrome in pre-diabetic men and women. J Int Soc Sports Nutr. 3, 45-53. 
Figure 1. Flowchart illustrating the selection process.
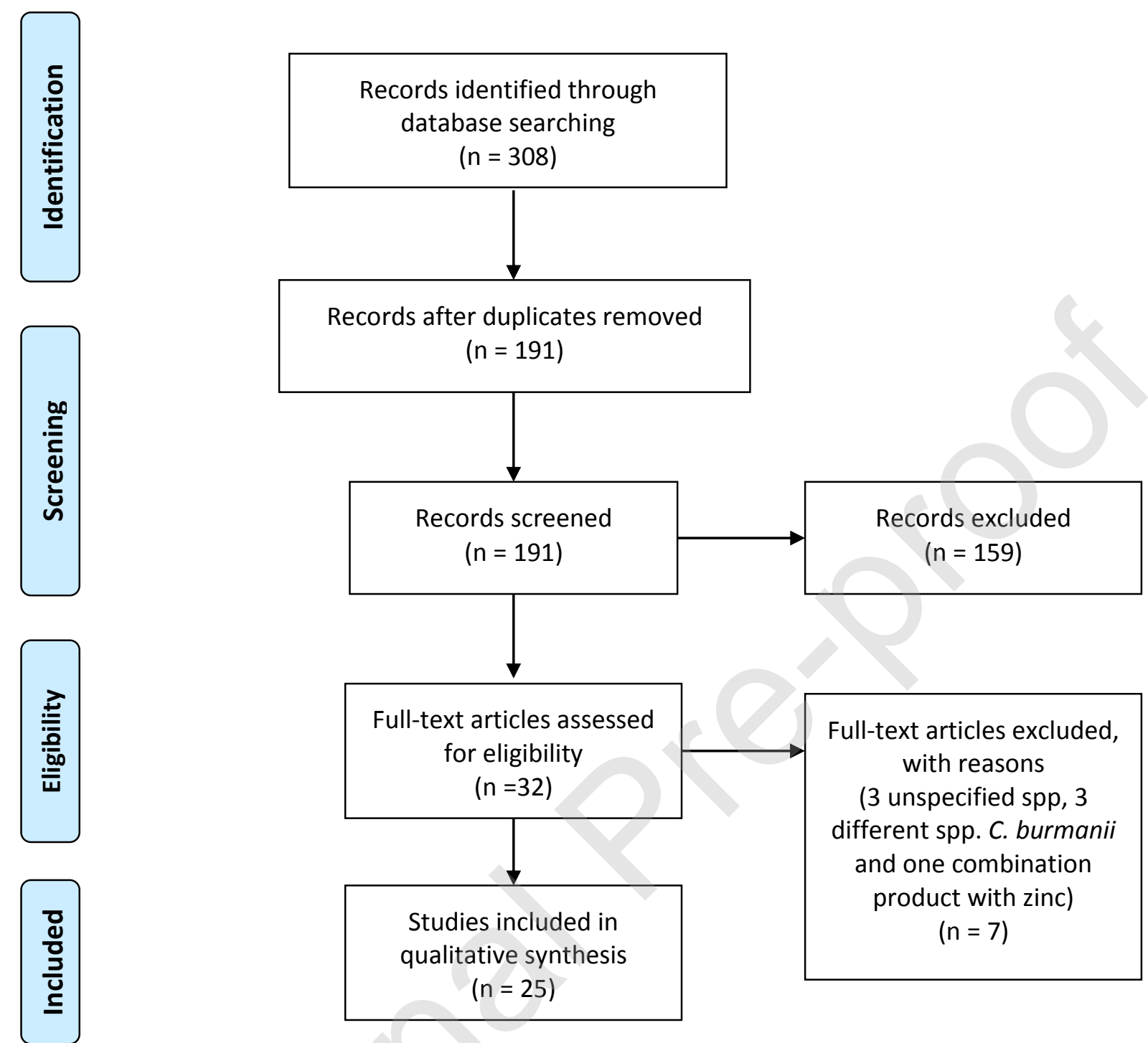
Table 1. Trials included in five previous reviews and current study

\begin{tabular}{|c|c|c|c|c|c|c|}
\hline & \multicolumn{5}{|c|}{ Previous reviews } & \multirow[b]{2}{*}{ Current study } \\
\hline & $\begin{array}{l}\text { Akilen et al. } \\
\text { (2012) }\end{array}$ & $\begin{array}{l}\text { Leach \& } \\
\text { Kumar } \\
(2012)\end{array}$ & $\begin{array}{l}\text { Allen et al. } \\
(2013)\end{array}$ & $\begin{array}{l}\text { Alanazi and } \\
\text { Khan } \\
11 \text { trials but } \\
16 \text { datasets } \\
\text { used from the } \\
11\end{array}$ & $\begin{array}{l}\text { Medagama } \\
(2015)\end{array}$ & \\
\hline Number of trials & 6 & 10 & 10 & 11 & 8 & 25 \\
\hline \multicolumn{7}{|c|}{ C. cassia } \\
\hline \multicolumn{7}{|c|}{ T2DM } \\
\hline Khan et al. (2003) & $\sqrt{ }$ & $\sqrt{ }$ & $\sqrt{ }$ & & $\sqrt{ }$ & $\sqrt{ }$ \\
\hline Mang et al. (2006) & $\sqrt{ }$ & $\sqrt{ }$ & $\sqrt{ }$ & $\sqrt{ }$ & $\sqrt{ }$ & $\sqrt{ }$ \\
\hline Suppapitiporn et al. (2006) & & $\sqrt{ }$ & $\sqrt{ }$ & $\sqrt{ }$ & $\sqrt{ }$ & $\sqrt{ }$ \\
\hline Vanschoonbeek et al. (2006) & $\sqrt{ }$ & $\sqrt{ }$ & $\sqrt{ }$ & $\sqrt{ }$ & $\sqrt{ }$ & $\sqrt{ }$ \\
\hline Blevins et al. (2007) & $\sqrt{ }$ & $\sqrt{ }$ & $\sqrt{ }$ & $\sqrt{ }$ & $\sqrt{ }$ & $\sqrt{ }$ \\
\hline Crawford (2009) & $\sqrt{ }$ & $\sqrt{ }$ & $\sqrt{ }$ & $\sqrt{ }$ & $\sqrt{ }$ & $\sqrt{ }$ \\
\hline Akilen et al. (2010) & $\sqrt{ }$ & $\sqrt{ }$ & $\sqrt{ }$ & $\sqrt{ }$ & $\sqrt{ }$ & $\sqrt{ }$ \\
\hline Lu et al. (2012) & & & $\sqrt{ }$ & $\sqrt{ }$ & & $\sqrt{ }$ \\
\hline Hasanzade et al. (2013) & & & & $\sqrt{ }$ & & $\sqrt{ }$ \\
\hline Gullapalli et al. (2013) & & & & $\sqrt{ }$ & & $\sqrt{ }$ \\
\hline Sengsuk et al. (2015) & & & & & & $\sqrt{ }$ \\
\hline Soni and Bhatnagar (2009) & & & & & 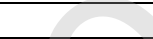 & $\sqrt{ }$ \\
\hline \multicolumn{7}{|l|}{ Related clinical conditions } \\
\hline $\begin{array}{l}\text { Magistrelli \& Chezem } \\
(2012)\end{array}$ & & & & & & $\sqrt{ }$ \\
\hline Wickenberg et al. (2014) & & & & 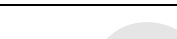 & & $\sqrt{ }$ \\
\hline Gutierrez et al. (2016) & & & & & 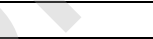 & $\sqrt{ }$ \\
\hline \multicolumn{7}{|c|}{ Healthy } \\
\hline Solomon \& Blannin (2007) & & & & & 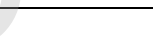 & $\sqrt{ }$ \\
\hline Hlebowicz et al. (2009) & & & & 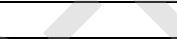 & & $\sqrt{ }$ \\
\hline Solomon \& Blannin (2009) & & & & se & 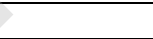 & $\sqrt{ }$ \\
\hline Mettler et al. (2009) & & & & & & $\sqrt{ }$ \\
\hline \multicolumn{7}{|c|}{ C. verum } \\
\hline \multicolumn{7}{|c|}{ T2DM } \\
\hline Vafa et al. (2012) & & & - & $\sqrt{ }$ & & $\sqrt{ }$ \\
\hline Azimi et al. (2014) & & & 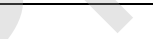 & & & $\sqrt{ }$ \\
\hline Azimi et al. (2016) & & - & & & & $\sqrt{ }$ \\
\hline \multicolumn{7}{|c|}{ Related clinical conditions } \\
\hline Wickenberg et al. (2012) & & & & & & $\sqrt{ }$ \\
\hline \multicolumn{7}{|c|}{ Healthy } \\
\hline Beejmohun et al. (2014) & & +3 & & & & $\sqrt{ }$ \\
\hline Markey et al. (2011) & & 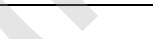 & & & & $\sqrt{ }$ \\
\hline \multicolumn{7}{|c|}{ Not C. cassia / C. verum, unidentified species or combined with other substances } \\
\hline Altschuler et al. (2007) & & $\sqrt{ }$ & & & & \\
\hline Khan et al. (2010) & & $\sqrt{ }$ & $\sqrt{ }$ & & & \\
\hline Rosado et al. (2010) & +2 & $\sqrt{ }$ & & & & \\
\hline Wainstein et al. (2011) & 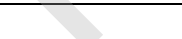 & & $\sqrt{ }$ & $\sqrt{ }$ & & \\
\hline Anderson et al. (2016) & & & & & $\sqrt{ }$ & \\
\hline & 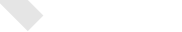 & & & & & \\
\hline Conclusion & $\begin{array}{l}\text { Effective } \\
\text { (significant } \\
\text { decrease in } \\
\text { HbAlc and } \\
\text { fasting blood } \\
\text { glucose } \\
\text { levels) }\end{array}$ & $\begin{array}{l}\text { Insufficient } \\
\text { evidence } \\
\text { (only } \\
\text { inconclusiv } \\
\text { e evidence } \\
\text { on fasting } \\
\text { blood } \\
\text { glucose; no } \\
\text { significant } \\
\text { effect on } \\
\text { HbA1c, } \\
\text { serum } \\
\text { insulin and } \\
\text { postprandia } \\
\text { 1 glucose) }\end{array}$ & $\begin{array}{c}\text { Effective } \\
\text { (improved } \\
\text { fasting } \\
\text { blood } \\
\text { glucose, } \\
\text { total } \\
\text { cholesterol, } \\
\text { LDL } \\
\text { cholesterol, } \\
\text { and } \\
\text { triglyceride } \\
\text { s. No } \\
\text { significant } \\
\text { effect on } \\
\text { HbA1c) }\end{array}$ & $\begin{array}{c}\text { Effective } \\
\text { (improved } \\
\text { fasting blood } \\
\text { glucose, total } \\
\text { cholesterol, } \\
\text { LDL } \\
\text { cholesterol, } \\
\text { and } \\
\text { triglycerides) }\end{array}$ & $\begin{array}{c}\text { Potentially } \\
\text { useful as an } \\
\text { adjuvant. }\end{array}$ & $\begin{array}{l}\text { C. cassia: } \\
\text { effective at } 3- \\
6 \mathrm{~g} \\
\text { C. verum: } \\
\text { insufficient } \\
\text { evidence }\end{array}$ \\
\hline
\end{tabular}


Table 2-1. Trials with T2DM patients

\begin{tabular}{|c|c|c|c|c|c|c|c|}
\hline $1^{\text {st }}$ Author & Population & Intervention & $\begin{array}{c}\text { Source of } \\
\text { cinnamon bark }\end{array}$ & Study design & Outcome & Safety & $\begin{array}{c}\text { Limitati } \\
\text { on }\end{array}$ \\
\hline \multicolumn{8}{|l|}{ C. cassia } \\
\hline $\begin{array}{l}\text { Sengsuk et } \\
\text { al. } 2015\end{array}$ & $\begin{array}{l}\text { Population: T2DM } \\
\text { patients aged } \\
57.2 \pm 1.1 \text { (treatment) } \\
\text { and } 56.9 \pm 1.2 \\
\text { (control) } \\
\text { Sample size: } \mathrm{n}=99 \\
\text { (treatment: } 49, \\
\text { control: } 50 \text { ) }\end{array}$ & $\begin{array}{l}\text { C. cassia } 1.5 \mathrm{~g} \text { per } \\
\text { day (after each } \\
\text { meal, } 0.5 \mathrm{~g} \text { each), } \\
\text { for } 60 \text { days }\end{array}$ & $\begin{array}{l}\text { Purchased from } \\
\text { Government } \\
\text { Pharmaceutical } \\
\text { Organization of } \\
\text { Thailand }\end{array}$ & $\begin{array}{l}\text { Study design: } \\
\text { randomised, } \\
\text { double-blind } \\
\text { Control: placebo }\end{array}$ & $\begin{array}{l}\text { Reduction in } \\
\text { glucose, } \\
\text { triglycerides, and } \\
\text { HbA1c levels. } \\
\text { Increase in HDL } \\
\text { and eGFR }\end{array}$ & $\begin{array}{l}\text { No } \\
\text { adverse } \\
\text { reactions }\end{array}$ & $\begin{array}{l}\text { No } \\
\text { voucher } \\
\text { specimen } \\
\text { number }\end{array}$ \\
\hline $\begin{array}{l}\text { Gullapalli } \\
\text { et al. } \\
\text { (2013) }\end{array}$ & $\begin{array}{l}\text { Population: T2DM } \\
\text { patients } \\
\text { Sample size: } n=60 \\
\text { (treatment: } 30, \\
\text { control: } 30 \text { ) }\end{array}$ & $\begin{array}{l}\text { C. cassia } 1 \mathrm{~g}, 3 \mathrm{~g} \text { or } \\
6 \mathrm{~g} \text { per day, for } 40 \\
\text { days. }\end{array}$ & $\begin{array}{l}\text { Certified by } \\
\text { Spice Board, } \\
\text { Kochi, Kerala }\end{array}$ & $\begin{array}{l}\text { Study design: } \\
\text { randomized } \\
\text { Control: placebo } \\
\text { (wheat flour) }\end{array}$ & $\begin{array}{l}1 \mathrm{~g}, 3 \mathrm{~g} \text { and } 6 \mathrm{~g} \text { all } \\
\text { reduced mean } \\
\text { fasting serum } \\
\text { glucose, } \\
\text { triglyceride, } \mathrm{LDL} \\
\text { and total } \\
\text { cholesterol. No } \\
\text { significant } \\
\text { changes in HDL. }\end{array}$ & $\begin{array}{l}\text { No } \\
\text { adverse } \\
\text { reactions }\end{array}$ & $\begin{array}{l}\text { No } \\
\text { voucher } \\
\text { specimen } \\
\text { number }\end{array}$ \\
\hline $\begin{array}{l}\text { Hasanzade } \\
\text { et al. } \\
\text { (2013) }\end{array}$ & $\begin{array}{l}\text { Population: T2DM } \\
\text { patients aged } \\
53.7 \pm 9.7 \text { (treatment) } \\
\text { and } 54.7 \pm 8.1 \\
\text { (control) } \\
\text { Sample size: } \mathrm{n}=71 \\
\text { (treatment: } 35, \\
\text { control: } 36 \text { ) }\end{array}$ & $\begin{array}{l}\text { C. cassia } 1 \mathrm{~g} \text { per } \\
\text { day (after } \\
\text { breakfast and } \\
\text { dinner } 0.5 \mathrm{~g} \text { each), } \\
\text { for } 30 \text { days }\end{array}$ & $\begin{array}{l}\text { Prepared by } \\
\text { collage of } \\
\text { pharmacy } \\
\text { (Mashhad } \\
\text { University of } \\
\text { Medical } \\
\text { Science) }\end{array}$ & $\begin{array}{l}\text { Study design: } \\
\text { randomised, } \\
\text { double-blind } \\
\text { Control: placebo }\end{array}$ & $\begin{array}{l}\text { No significant } \\
\text { effect on fasting } \\
\text { blood glucose and } \\
\text { HbA1c levels }\end{array}$ & $\begin{array}{l}\text { Not } \\
\text { mentione } \\
\mathrm{d}\end{array}$ & $\begin{array}{l}\text { No } \\
\text { voucher } \\
\text { specimen } \\
\text { number }\end{array}$ \\
\hline $\begin{array}{l}\text { Lu } \text { et al. } \\
\text { (2012) }\end{array}$ & $\begin{array}{l}\text { Population: Chinese } \\
\text { patients with T2DM, } \\
\text { taking sulfonylurea, } \\
\text { aged around } 60 \\
\text { Sample size: } n=66 \\
\text { (placebo: } 20, \text { low- } \\
\text { dose: } 23 \text {, high-dose: } \\
\text { 23) }\end{array}$ & $\begin{array}{l}\text { C. cassia aqueous } \\
\text { extract } 120 \mathrm{mg} \\
\text { (from } 2.8 \mathrm{~g} \text { of } C \text {. } \\
\text { cassia) or } 360 \mathrm{mg} \\
\text { per day for } 3 \\
\text { months. }\end{array}$ & $\begin{array}{l}\text { Produced by } \\
\text { Shanghai } \\
\text { Jinsijia Health- } \\
\text { Care Food Co, } \\
\text { Ltd (Shanghai, } \\
\text { China), batch } \\
\text { number } \\
20090901\end{array}$ & $\begin{array}{l}\text { Study design: } \\
\text { randomised, } \\
\text { double-blind } \\
\text { Control: placebo }\end{array}$ & $\begin{array}{l}\text { Decrease in } \\
\text { HbAlc and } \\
\text { fasting glucose } \\
\text { levels (120mg and } \\
360 \mathrm{mg} \text { extract). } \\
\text { Decrease in } \\
\text { triglyceride } \\
\text { treatment group } \\
(120 \mathrm{mg}) \text {. }\end{array}$ & $\begin{array}{l}\text { No } \\
\text { adverse } \\
\text { reactions }\end{array}$ & \\
\hline $\begin{array}{l}\text { Akilen } \text { et } \\
\text { al. (2010) }\end{array}$ & $\begin{array}{l}\text { Population: T2DM } \\
\text { patients taking oral } \\
\text { hypoglycaemic } \\
\text { agents, multi-ethnic, } \\
\text { aged } 54.9 \pm 9.8 \\
\text { Sample size: } \mathrm{n}=58 \\
\text { (treatment: } 30, \\
\text { control: } 28)\end{array}$ & $\begin{array}{l}\text { C. cassia } 2 \mathrm{~g} \text { per } \\
\text { day for } 12 \text { weeks }\end{array}$ & $\begin{array}{l}\text { Certified } \\
\text { (reference: } \\
\text { HBL14020NB) }\end{array}$ & $\begin{array}{l}\text { Study design: } \\
\text { randomised, } \\
\text { double-blind, } \\
\text { parallel } \\
\text { Control: placebo }\end{array}$ & $\begin{array}{l}\text { Decrease in } \\
\text { HbA1c, Systolic } \\
\text { and diastolic } \\
\text { blood pressure. }\end{array}$ & $\begin{array}{l}\text { Safe and } \\
\text { well } \\
\text { tolerated }\end{array}$ & \\
\hline $\begin{array}{l}\text { Crawford } \\
\text { (2009) }\end{array}$ & $\begin{array}{l}\text { Population: T2DM } \\
\text { patients, multi- } \\
\text { ethnic, aged around } \\
60 \\
\text { Sample size: } \mathrm{n}=109 \\
\text { (treatment: } 55, \\
\text { control: } 54 \text { ) }\end{array}$ & $\begin{array}{l}\text { C. cassia } 1 \mathrm{~g} \text { each } \\
\text { day with meal, for } \\
90 \text { days }\end{array}$ & $\begin{array}{l}\text { Puritan's } \\
\text { Pride, Oakdale, } \\
\text { NY }\end{array}$ & $\begin{array}{l}\text { Study design: } \\
\text { stratified } \\
\text { randomisation, } \\
\text { parallel } \\
\text { Control: usual } \\
\text { management care }\end{array}$ & $\begin{array}{l}\text { Significant } \\
\text { reduction in } \\
\text { HbA1c levels in } \\
\text { the treatment } \\
\text { group, compared } \\
\text { to moderate } \\
\text { reduction in } \\
\text { control group. }\end{array}$ & $\begin{array}{l}\text { One } \\
\text { subject in } \\
\text { the } \\
\text { treatment } \\
\text { group } \\
\text { reported } \\
\text { developin } \\
\text { g a rash. }\end{array}$ & $\begin{array}{l}\text { Not } \\
\text { blinded }\end{array}$ \\
\hline $\begin{array}{l}\text { Soni \& } \\
\text { Bhatnagar } \\
(2009)\end{array}$ & $\begin{array}{l}\text { Population: T2DM } \\
\text { male patients aged } \\
40-60 \\
\text { Sample size: } \mathrm{n}=30 \\
\text { (treatment: } 15, \\
\text { control: } 15 \text { ) }\end{array}$ & $\begin{array}{l}\text { C. cassia 2g per } \\
\text { day (after } \\
\text { breakfast, lunch, } \\
\text { evening tea, and } \\
\text { dinner, a quarter } \\
\text { each), for } 40 \text { days }\end{array}$ & No information & $\begin{array}{l}\text { Study design: } \\
\text { controlled } \\
\text { Control: no } \\
\text { supplementation }\end{array}$ & $\begin{array}{l}\text { Decrease in } \\
\text { fasting and } \\
\text { postprandial blood } \\
\text { glucose levels }\end{array}$ & $\begin{array}{l}\text { Not } \\
\text { mentione } \\
\text { d. }\end{array}$ & $\begin{array}{l}\text { The } \\
\text { source of } \\
\text { C. cassia } \\
\text { is } \\
\text { unknown }\end{array}$ \\
\hline $\begin{array}{l}\text { Blevins et } \\
\text { al. (2007) }\end{array}$ & $\begin{array}{l}\text { Population: T2DM } \\
\text { patients } \\
\text { Sample size: } \mathrm{n}=57 \\
\text { (treatment: } 29, \\
\text { control: 28) }\end{array}$ & $\begin{array}{l}\text { C. cassia } 1 \mathrm{~g} \text { per } \\
\text { day }(2 \mathrm{x} 0.5 \mathrm{~g} \\
\text { capsules, one with } \\
\text { breakfast one with } \\
\text { dinner), for } 3 \\
\text { months }\end{array}$ & No information & $\begin{array}{l}\text { Study design: } \\
\text { stratified } \\
\text { randomisation, } \\
\text { double-blind } \\
\text { Control: placebo } \\
\text { capsules } \\
\text { containing wheat } \\
\text { flour }\end{array}$ & $\begin{array}{l}\text { No effect on } \\
\text { fasting glucose, } \\
\text { lipid, and insulin } \\
\text { levels. }\end{array}$ & $\begin{array}{l}\text { Not } \\
\text { mentione } \\
\text { d. }\end{array}$ & $\begin{array}{l}\text { The } \\
\text { source of } \\
\text { C. cassia } \\
\text { is } \\
\text { unknown } \\
\text {. }\end{array}$ \\
\hline $\begin{array}{l}\text { Suppapitip } \\
\text { orn } \text { et al. } \\
\text { (2006) }\end{array}$ & $\begin{array}{l}\text { Population: T2DM } \\
\text { patients } \\
\text { Sample size: } \mathrm{n}=60 \\
\text { (treatment: } 20 ; \\
\text { control 40) }\end{array}$ & $\begin{array}{l}\text { C. cassia } 1.5 \mathrm{~g} \text { per } \\
\text { day, for } 12 \text { weeks. }\end{array}$ & No information & $\begin{array}{l}\text { Study design: } \\
\text { randomized, } \\
\text { single blind }\end{array}$ & $\begin{array}{l}\text { No decrease in } \\
\text { HbA1c, lipid } \\
\text { profile, fasting } \\
\text { plasma glucose. }\end{array}$ & $\begin{array}{l}\text { No } \\
\text { adverse } \\
\text { reactions }\end{array}$ & $\begin{array}{l}\text { The } \\
\text { source of } \\
\text { C. cassia } \\
\text { is }\end{array}$ \\
\hline
\end{tabular}




\begin{tabular}{|c|c|c|c|c|c|c|c|}
\hline & & & & & $\begin{array}{l}\text { Reduction in } \\
\text { SGOT (AST). }\end{array}$ & & $\begin{array}{l}\text { unknown } \\
\text {. }\end{array}$ \\
\hline $\begin{array}{l}\text { Mang et al. } \\
(2006)\end{array}$ & $\begin{array}{l}\text { Population: T2DM } \\
\text { patients (not on } \\
\text { insulin therapy), } \\
\text { aged } 31.1 \pm 2.0 \\
\text { Sample size: } \mathrm{n}=65 \\
\text { (treatment: } 33 \text {, } \\
\text { control: } 32 \text { ) }\end{array}$ & $\begin{array}{l}\text { C. cassia aqueous } \\
\text { extract } 336 \mathrm{mg} \\
\text { (equivalent to } 3 \mathrm{~g} \\
\text { of } \text { C.cassia) daily } \\
\text { (capsules } 1 \mathrm{~g} \text { x } 3 \\
\text { times a day), for } 4 \\
\text { months }\end{array}$ & $\begin{array}{l}\text { Cinnamon } \\
\text { extract TC112 } \\
\text { prepared by } \\
\text { Finzelberg } \\
\text { (Andernach, } \\
\text { Germany) }\end{array}$ & $\begin{array}{l}\text { Study design: } \\
\text { randomised, } \\
\text { double-blinded. } \\
\text { Control: placebo } \\
\text { capsules with } \\
\text { microcrystalline } \\
\text { cellulose }\end{array}$ & $\begin{array}{l}\text { Decrease in } \\
\text { fasting plasma } \\
\text { glucose levels. }\end{array}$ & $\begin{array}{l}\text { No } \\
\text { adverse } \\
\text { reactions. }\end{array}$ & \\
\hline $\begin{array}{l}\text { Vanschoon } \\
\text { beek et al. } \\
(2006)\end{array}$ & $\begin{array}{l}\text { Population: } \\
\text { postmenopausal } \\
\text { patients with T2DM, } \\
\text { aged } 62.9 \pm 1.5 \text {. } \\
\text { Sample size: } \mathrm{n}=25 \\
\text { (treatment: } 13 \text {, } \\
\text { control: } 12 \text { ) }\end{array}$ & $\begin{array}{l}\text { C. cassia } 1.5 \mathrm{~g} \text { per } \\
\text { day }(0.5 \mathrm{~g} \times 3 \\
\text { times a day after } \\
\text { each meal), for } 2 \\
\text { and } 6 \text { weeks }\end{array}$ & Verstegen brand & $\begin{array}{l}\text { Study design: } \\
\text { stratified } \\
\text { randomisation, } \\
\text { double-blinded. } \\
\text { Control: placebo } \\
\text { (wheat flour) }\end{array}$ & $\begin{array}{l}\text { No effect on } \\
\text { postprandial } \\
\text { glucose and } \\
\text { insulin levels, } \\
\text { fasting lipid } \\
\text { levels, at } 2 \text { weeks } \\
\text { and } 6 \text { weeks. }\end{array}$ & $\begin{array}{l}\text { Not } \\
\text { mentione } \\
\text { d. }\end{array}$ & $\begin{array}{l}\text { Small } \\
\text { sample } \\
\text { size }\end{array}$ \\
\hline $\begin{array}{l}\text { Khan et al. } \\
(2003)\end{array}$ & $\begin{array}{l}\text { Population: T2DM } \\
\text { patients, taking } \\
\text { sulfonylurea, } \\
\text { average age } 52.0 \\
\text { Sample size: } \mathrm{n}=30 \\
\text { (10 per group) }\end{array}$ & $\begin{array}{l}\text { C. cassia } 1 \mathrm{~g}, 3 \mathrm{~g} \text {, } \\
\text { or } 6 \mathrm{~g} \text { per day, } \\
\text { after lunch and } \\
\text { dinner, for } 40 \\
\text { days }\end{array}$ & $\begin{array}{l}\text { Certified by the } \\
\text { Office of the } \\
\text { Director, } \\
\text { Research and } \\
\text { Development/N } \\
\text { on-Timber } \\
\text { Forest Products, } \\
\text { NWFP Forest } \\
\text { Department, } \\
\text { Peshawar, } \\
\text { Pakistan } \\
\end{array}$ & $\begin{array}{l}\text { Study design: } \\
\text { randomised. } \\
\text { Control: placebo } \\
\text { (wheat flour) }\end{array}$ & $\begin{array}{l}\text { Decrease in } \\
\text { fasting serum } \\
\text { glucose, } \\
\text { triglyceride, and } \\
\text { LDL cholesterol } \\
\text { levels, at } 20,40, \\
\text { and } 60 \text { days. }\end{array}$ & $\begin{array}{l}\text { Not } \\
\text { mentione } \\
\text { d. }\end{array}$ & $\begin{array}{l}\text { Small } \\
\text { sample } \\
\text { size }\end{array}$ \\
\hline \multicolumn{8}{|l|}{ C. verum } \\
\hline $\begin{array}{l}\text { Azimi et } \\
\text { al. }(2016)\end{array}$ & $\begin{array}{l}\text { Population: T2DM } \\
\text { patients } \\
\text { Sample size: } n=79 \\
\text { (treatment: } 40, \\
\text { control: } 39 \text { ) }\end{array}$ & $\begin{array}{l}\text { C. verum } 3 \mathrm{~g} \text { with } \\
\text { black tea for } 8 \\
\text { weeks }\end{array}$ & $\begin{array}{l}\text { Approved by } \\
\text { the Ministry of } \\
\text { Health (License } \\
\text { No. } 16 / 13777)\end{array}$ & $\begin{array}{l}\text { Study design: } \\
\text { randomised, } \\
\text { single-blind, } \\
\text { parallel. } \\
\text { Control: black tea } \\
\text { only }\end{array}$ & $\begin{array}{l}\text { No effect on } \\
\text { blood pressure } \\
\text { and endothelial } \\
\text { function. }\end{array}$ & $\begin{array}{l}\text { No } \\
\text { adverse } \\
\text { reactions }\end{array}$ & $\begin{array}{l}\text { Processe } \\
\mathrm{d} \\
\text { cinnamon }\end{array}$ \\
\hline $\begin{array}{l}\text { Azimi } \text { et } \\
\text { al. }(2014)\end{array}$ & $\begin{array}{l}\text { Population: T2DM } \\
\text { patients } \\
\text { Sample size: } n=79 \\
\text { (treatment: } 40, \\
\text { control: } 39 \text { ) }\end{array}$ & $\begin{array}{l}\text { C. verum } 3 \mathrm{~g} \text { with } \\
\text { black tea, for } 8 \\
\text { weeks }\end{array}$ & $\begin{array}{l}\frac{\text { Approved by }}{\text { the Ministry of }} \\
\frac{\text { Health (License }}{\text { No.16/13777) }}\end{array}$ & $\begin{array}{l}\text { Study design: } \\
\text { randomised, } \\
\text { single-blind, } \\
\text { parallel. } \\
\text { Control: black tea } \\
\text { only }\end{array}$ & $\begin{array}{l}\text { Decrease in } \\
\text { fasting blood } \\
\text { glucose. } \\
\text { No effect insulin } \\
\text { and HbA1c but } \\
\text { only } 8 \text { weeks }\end{array}$ & $\begin{array}{l}\text { No } \\
\text { adverse } \\
\text { reactions }\end{array}$ & $\begin{array}{l}\text { Processe } \\
\mathrm{d} \\
\text { cinnamon }\end{array}$ \\
\hline $\begin{array}{l}\text { Vafa et al. } \\
(2012)\end{array}$ & $\begin{array}{l}\text { Population: T2DM } \\
\text { patients, sample size: } \\
\text { n=44 (treatment: } 22 \text {, } \\
\text { control: } 22 \text { ) }\end{array}$ & $\begin{array}{l}\text { C. verum } 3 \mathrm{~g} \text { per } \\
\text { day for } 8 \text { weeks }\end{array}$ & No information & $\begin{array}{l}\text { Study design: } \\
\text { double blind, } \\
\text { randomized. } \\
\text { Control: placebo } \\
\text { (wheat flour) }\end{array}$ & $\begin{array}{l}\text { Outcome: } \\
\text { decrease in fasting } \\
\text { blood glucose, } \\
\text { HbA1c, } \\
\text { triglyceride, } \\
\text { weight, BMI and } \\
\text { body fat mass }\end{array}$ & $\begin{array}{l}\text { No } \\
\text { adverse } \\
\text { reactions }\end{array}$ & \\
\hline
\end{tabular}


Table 2-2. Trials with related clinical conditions

\begin{tabular}{|c|c|c|c|c|c|c|c|}
\hline $1^{\text {st }}$ Author & Population & Intervention & $\begin{array}{l}\text { Source of } \\
\text { cinnamon } \\
\text { bark }\end{array}$ & Study design & Outcome & Safety & $\begin{array}{l}\text { Limitati } \\
\text { on }\end{array}$ \\
\hline \multicolumn{8}{|l|}{ C. cassia } \\
\hline $\begin{array}{l}\text { Gutierrez } \\
\text { et al. } \\
\text { (2016) }\end{array}$ & $\begin{array}{l}\text { Population: } \\
\text { sedentary and obese } \\
\text { females aged } 22.7 \pm 4 \\
\text { Sample size: } \mathrm{n}=10\end{array}$ & $\begin{array}{l}\text { C. cassia 5g } \\
\text { (capsules) } \\
\text { with OGTT }\end{array}$ & $\begin{array}{l}\text { Nature's } \\
\text { Bounty, } \\
\text { Bohemia, } \\
\text { NY }\end{array}$ & $\begin{array}{l}\text { Study design: } \\
\text { crossover } \\
\text { Control: placebo } \\
\text { (placebo) }\end{array}$ & $\begin{array}{l}\text { Lower response to } \\
\text { oral glucose } \\
\text { tolerance test. No } \\
\text { difference in } \\
\text { insulin resistance } \\
\text { and sensitivity. }\end{array}$ & $\begin{array}{l}\text { Not } \\
\text { mentione } \\
\text { d. }\end{array}$ & $\begin{array}{l}\text { Small } \\
\text { sample } \\
\text { size }\end{array}$ \\
\hline $\begin{array}{l}\text { Wickenber } \\
\text { g, J. et al. } \\
\text { (2014) }\end{array}$ & $\begin{array}{l}\text { Population: IGT, } \\
\text { aged around } 72 \\
\text { Sample size: } \mathrm{n}=17 \\
\text { (treatment: } 8, \\
\text { control: 9) }\end{array}$ & $\begin{array}{l}12 \mathrm{~g} \text { C. cassia } \\
\text { per day, for } \\
12 \text { weeks. }\end{array}$ & $\begin{array}{l}\text { Svampbutik } \\
\text { en, } \\
\text { Mediapoint } \\
\mathrm{AB}, \\
\text { Västerås, } \\
\text { Sweden }\end{array}$ & $\begin{array}{l}\text { Study design: } \\
\text { stratified } \\
\text { randomised, double- } \\
\text { blind, parallel } \\
\text { Control: placebo } \\
\text { (cellulose) }\end{array}$ & $\begin{array}{l}\text { No effects on } \\
\text { fasting-insulin, } \\
\text { glucose, HbA1c, } \\
\text { cholesterol levels, } \\
\text { triglycerides, and } \\
\text { liver enzymes. }\end{array}$ & $\begin{array}{l}\text { Not } \\
\text { mentione } \\
\text { d. No } \\
\text { change in } \\
\text { serum } \\
\text { transamin } \\
\text { ases. }\end{array}$ & $\begin{array}{l}\text { Small } \\
\text { sample } \\
\text { size }\end{array}$ \\
\hline $\begin{array}{l}\text { Magistrelli } \\
\text { \& Chezem } \\
\text { (2012) }\end{array}$ & $\begin{array}{l}\text { Populations: normal } \\
\text { (BMI 21.1 } 1.1 \text {, aged } \\
21.0 \pm 2.5 \text { ) } \\
\text { and obese (BMI } \\
33.1 \pm 4.6 \text {, aged } \\
22.1 \pm 2.4 \text { ) } \\
\text { Sample size: } \mathrm{n}=45 \\
\text { (normal: } 30, \text { obese: } \\
\text { 15) }\end{array}$ & $\begin{array}{l}\text { Cereal } \\
\text { prepared with } \\
\text { C. cassia } 6 \mathrm{~g}\end{array}$ & $\begin{array}{l}\text { Swagger } \\
\text { Foods, } \\
\text { Vernon } \\
\text { Hills, IL }\end{array}$ & $\begin{array}{l}\text { Study design: } \\
\text { randomised, cross- } \\
\text { over } \\
\text { Control: plain cereal }\end{array}$ & $\begin{array}{l}\text { Slower } \\
\text { postprandial blood } \\
\text { glucose rise }\end{array}$ & $\begin{array}{l}\text { Not } \\
\text { mentione } \\
\text { d. }\end{array}$ & $\begin{array}{l}\text { Not } \\
\text { blinded }\end{array}$ \\
\hline \multicolumn{8}{|l|}{ C. verum } \\
\hline $\begin{array}{l}\text { Wickenber } \\
\text { g } \text { et al. } \\
\text { (2012) }\end{array}$ & $\begin{array}{l}\text { Population: IGT, } \\
\text { aged 29-73 } \\
\text { Sample size: } \\
\mathrm{n}=10\end{array}$ & $\begin{array}{l}\text { C. verum } 6 \mathrm{~g} \\
\text { with OGTT }\end{array}$ & $\begin{array}{l}\text { Svampbutik } \\
\text { en, } \\
\text { Mediapoint } \\
\mathrm{AB} \text {, } \\
\text { Västerås, } \\
\text { Sweden }\end{array}$ & $\begin{array}{l}\text { Study design: } \\
\text { randomised, cross- } \\
\text { over (at intervals of } \\
1 \text { week) } \\
\text { Control: placebo } \\
\text { capsules (lactose) }\end{array}$ & $\begin{array}{l}\text { No effect on } \\
\text { postprandial } \\
\text { plasma glucose } \\
\text { and insulin. }\end{array}$ & $\begin{array}{l}\text { Not } \\
\text { mentione } \\
\text { d. }\end{array}$ & $\begin{array}{l}\text { Small } \\
\text { sample } \\
\text { size }\end{array}$ \\
\hline
\end{tabular}


Table 2-3. Trials with healthy populations

\begin{tabular}{|c|c|c|c|c|c|c|c|}
\hline $1^{\text {st }}$ Author & Population & Intervention & $\begin{array}{l}\text { Source } \\
\text { of } \\
\text { cinnamo } \\
\text { n bark } \\
\end{array}$ & Study design & Outcome & Safety & $\begin{array}{l}\text { Limitati } \\
\text { on }\end{array}$ \\
\hline \multicolumn{8}{|l|}{ C. cassia } \\
\hline $\begin{array}{l}\text { Hlebowicz } \\
\text { et al. } \\
\text { (2009) }\end{array}$ & $\begin{array}{l}\text { Population: } \\
\text { healthy, aged } \\
\text { between 20-27 } \\
\text { Sample size: } \\
\mathrm{n}=15\end{array}$ & $\begin{array}{l}\text { Rice pudding } \\
\text { mixed with } 1 \text { or } \\
\text { 3g C. cassia. } \\
\text { Single } \\
\text { administration }\end{array}$ & $\begin{array}{l}\text { Santa } \\
\text { Maria } \\
\text { AB, } \\
\text { Mölndal, } \\
\text { Sweden }\end{array}$ & $\begin{array}{l}\text { Study design: } \\
\text { randomised, } \\
\text { cross-over } \\
\text { Control: plain rice } \\
\text { pudding }\end{array}$ & $\begin{array}{l}\text { Decrease in } \\
\text { postprandial insulin } \\
\text { rise. Increase in the } \\
\text { release of glucagon } \\
\text { like peptide } 1 \text { (GLP- } \\
\text { 1) (3g C. cassia } \\
\text { group only) }\end{array}$ & $\begin{array}{l}\text { Not } \\
\text { mentione } \\
\text { d. }\end{array}$ & $\begin{array}{l}\text { Not } \\
\text { blinded. }\end{array}$ \\
\hline $\begin{array}{l}\text { Mettler } e t \\
\text { al. (2009) }\end{array}$ & $\begin{array}{l}\text { Population: } \\
\text { healthy } \\
\text { Sample size: } \\
\mathrm{n}=27\end{array}$ & $\begin{array}{l}\text { Sugar drink and } \\
\text { milk rice meal } \\
\text { with: } \\
\text { 1. C.cassia } 4 \mathrm{~g} \\
\text { in the meal } \\
\text { 2. vinegar in the } \\
\text { sugar drink } \\
\text { 3. C.cassia + } \\
\text { vinegar } \\
\text { Single } \\
\text { administration. }\end{array}$ & $\begin{array}{l}\text { Gewürzm } \\
\text { ühle } \\
\text { Brecht } \\
\text { GmbH, } \\
\text { Eggenstei } \\
\text { n, } \\
\text { Germany }\end{array}$ & $\begin{array}{l}\text { Study design: } \\
\text { randomised, } \\
\text { cross-over } \\
\text { Control: sugar } \\
\text { drink and plain } \\
\text { milk rice meal }\end{array}$ & $\begin{array}{l}\text { (1) No difference for } \\
\text { C.cassia alone. (2) } \\
\text { Postprandial glucose } \\
\text { levels lower for } \\
\text { C.cassia + vinegar. }\end{array}$ & $\begin{array}{l}\text { Not } \\
\text { mentione } \\
\text { d. }\end{array}$ & $\begin{array}{l}\text { Not } \\
\text { blinded. }\end{array}$ \\
\hline $\begin{array}{l}\text { Solomon \& } \\
\text { Blannin } \\
\text { (2009) }\end{array}$ & $\begin{array}{l}\text { Population: } \\
\text { healthy, aged } \\
25 \pm 1 \\
\text { Sample size: } \\
\mathrm{n}=8\end{array}$ & $\begin{array}{l}\text { C. cassia } 3 \mathrm{~g} \text { per } \\
\text { day, for } 14 \text { days }\end{array}$ & $\begin{array}{l}\text { Everythin } \\
\text { gcinnamo } \\
\text { n.com, } \\
\text { Essex, } \\
\text { UK }\end{array}$ & $\begin{array}{l}\text { Study design: } \\
\text { randomised, } \\
\text { single blind, } \\
\text { placebo } \\
\text { controlled, cross- } \\
\text { over } \\
\text { Control: placebo } \\
\text { (wheat flour) }\end{array}$ & $\begin{array}{l}\text { Decrease in } \\
\text { postprandial glucose } \\
\text { levels and insulin } \\
\text { levels. }\end{array}$ & $\begin{array}{l}\text { Not } \\
\text { mentione } \\
\text { d. }\end{array}$ & $\begin{array}{l}\text { Small } \\
\text { sample } \\
\text { size }\end{array}$ \\
\hline $\begin{array}{l}\text { Solomon \& } \\
\text { Blannin } \\
\text { (2007) }\end{array}$ & $\begin{array}{l}\text { Population: } \\
\text { healthy male } \\
\text { volunteers, aged } \\
26 \pm 1 \\
\text { Sample size: } \\
\mathrm{n}=7\end{array}$ & $\begin{array}{l}\text { (1) OCTT } \\
\text { supplemented } \\
\text { with } 5 \mathrm{~g} \\
\text { C.cassia } \\
\text { (2) } 5 \mathrm{~g} \text { C.cassia } \\
\text { capsules } 12 \mathrm{~h} \\
\text { before OCTT. } \\
\text { Single } \\
\text { administration }\end{array}$ & $\begin{array}{l}\text { Everythin } \\
\text { gcinnamo } \\
\text { n.com, } \\
\text { Essex, } \\
\text { UK }\end{array}$ & $\begin{array}{l}\text { Study design: } \\
\text { randomised, } \\
\text { cross-over, } \\
\text { placebo controlled } \\
\text { Control: placebo } \\
\text { capsules with 5g } \\
\text { wheat flour }\end{array}$ & $\begin{array}{l}\text { Decrease in } \\
\text { postprandial plasma } \\
\text { glucose. Increase in } \\
\text { insulin sensitivity by } \\
\text { one index (Matsuda) } \\
\text { but not in another } \\
\text { index (HOMA). }\end{array}$ & $\begin{array}{l}\text { Not } \\
\text { mentione } \\
\text { d. }\end{array}$ & $\begin{array}{l}\text { Small } \\
\text { sample } \\
\text { size }\end{array}$ \\
\hline $\begin{array}{l}\text { Beejmohun } \\
\text { et al. } \\
\text { (2014) }\end{array}$ & $\begin{array}{l}\text { Population: } \\
\text { healthy, aged } \\
29.9 \pm 1.8 \\
\text { Sample size: } \\
\mathrm{n}=18\end{array}$ & $\begin{array}{l}\text { Single } \\
\text { administration. } \\
C \text {. verum hydro- } \\
\text { alcoholic } \\
(50 / 50) \text { extract } \\
1 \mathrm{~g} \text { after a } \\
\text { standardised } \\
\text { meal }\end{array}$ & $\begin{array}{l}\text { MealSha } \\
\text { pe } \\
\text { trademar } \\
\mathrm{k}\end{array}$ & $\begin{array}{l}\text { Study design: } \\
\text { randomised, } \\
\text { double-blind, } \\
\text { placebo- } \\
\text { controlled, cross- } \\
\text { over } \\
\text { Control: placebo }\end{array}$ & $\begin{array}{l}\text { Decrease in } \\
\text { postprandial } \\
\text { hyperglycaemia. }\end{array}$ & $\begin{array}{l}\text { No } \\
\text { adverse } \\
\text { reaction. }\end{array}$ & \\
\hline \multicolumn{8}{|l|}{ C. verum } \\
\hline $\begin{array}{l}\text { Markey et } \\
\text { al. (2011) }\end{array}$ & $\begin{array}{l}\text { Population: } \\
\text { healthy, aged } \\
26.2 \pm 3 \\
\text { Sample size: } \\
\mathrm{n}=9\end{array}$ & $\begin{array}{l}\text { A high-fat meal, } \\
\text { with } C \text {. verum } \\
\text { 3g. Single dose. }\end{array}$ & $\begin{array}{l}\text { Schwartz } \\
\text {, UK }\end{array}$ & $\begin{array}{l}\text { Study design: } \\
\text { randomised, } \\
\text { placebo- } \\
\text { controlled, single- } \\
\text { blinded, cross- } \\
\text { over } \\
\text { Control: placebo } \\
\text { (wheat flour) } \\
\end{array}$ & $\begin{array}{l}\text { No effect on the } \\
\text { postprandial levels } \\
\text { of triacylglycerol, } \\
\text { glucose, oxidative } \\
\text { stress, arterial } \\
\text { function, or appetite, } \\
\text { in response to a } \\
\text { high-fat test meal. }\end{array}$ & $\begin{array}{l}\text { Not } \\
\text { mentione } \\
\text { d. }\end{array}$ & $\begin{array}{l}\text { Small } \\
\text { sample } \\
\text { size }\end{array}$ \\
\hline
\end{tabular}


Table 3. Coumarin contents of cinnamon species

\begin{tabular}{|c|c|c|c|c|c|c|}
\hline $\begin{array}{c}1^{\text {st }} \begin{array}{c}\text { Author } \\
\text { (year) }\end{array} \\
\end{array}$ & Aim of the study & Materials & Method & $\begin{array}{c}\text { Coumarin } \\
\text { contents }\end{array}$ & Notes & $\begin{array}{c}\text { Source of plant } \\
\text { materials }\end{array}$ \\
\hline \multicolumn{7}{|c|}{ Coumarin levels } \\
\hline $\begin{array}{l}\text { Krieger et al. } \\
\quad(2013)\end{array}$ & $\begin{array}{l}\text { Methodological } \\
\text { study on the } \\
\text { detection of } \\
\text { coumarins using } \\
\text { DIP-APCI-MS and } \\
\text { LC-MS }\end{array}$ & $\begin{array}{l}\text { C. verum and } C \text {. } \\
\text { cassia powder } \\
\text { from different } \\
\text { origins ( } \mathrm{n}=5 \text { for } \\
\text { C. verum and } \mathrm{n}=2 \\
\text { for } \text { cassia) }\end{array}$ & $\begin{array}{l}\text { Extraction: } \\
80 \% \text { methanol } \\
(0.5 \mathrm{~g} / 40 \mathrm{~mL}) \\
\text { Analysis: } \\
\text { LC-MS and } \\
\text { DIP-APCI-MS } \\
\text { analyses }\end{array}$ & $\begin{array}{l}\text { C. verum: } 0.092- \\
0.427 \mathrm{~g} / \mathrm{kg} \\
\text { C. } \text { cassia: } \\
2.512-2.628 \\
\mathrm{~g} / \mathrm{kg}\end{array}$ & $\begin{array}{l}\text { C. cassia contains } \\
\text { considerably higher } \\
\text { levels of coumarin. }\end{array}$ & No information \\
\hline $\begin{array}{l}\text { Wang et al. } \\
\text { (2013) }\end{array}$ & $\begin{array}{l}\text { To analyse coumarin } \\
\text { and other } \\
\text { compounds in } \\
\text { different cinnamon } \\
\text { species and } \\
\text { cinnamon } \\
\text { containing foods and } \\
\text { supplements }\end{array}$ & $\begin{array}{l}\text { C. verum, } C \text {. } \\
\text { cassia, } C \text {. } \\
\text { loureiroi, and } C \text {. } \\
\text { burmannii from } \\
\text { different origins } \\
\text { (n=16 for } C \text {. } \\
\text { verum; } \mathrm{n}=3 \text { for } C \text {. } \\
\text { cassia } ; \mathrm{n}=1 \text { for } C \text {. } \\
\text { loureiroi } ; \mathrm{n}=7 \text { for } \\
\text { C. burmannii) }\end{array}$ & $\begin{array}{l}\text { Extraction: } \\
\text { Methanol } \\
(0.5 \mathrm{~g} / 2.5 \mathrm{~mL} \text {, } \\
\text { sonication for } \\
\text { 30min, } 3 \text { times }) \\
\text { Analysis: } \\
\text { UPLC-UV/MS }\end{array}$ & $\begin{array}{l}\text { C. verum: } 0.007- \\
0.090 \mathrm{~g} / \mathrm{kg} \\
\text { C. } \text { cassia: } 0.085- \\
0.310 \mathrm{~g} / \mathrm{kg} \\
\text { C. loureiroi: } \\
1.06-6.97 \mathrm{~g} / \mathrm{kg} \\
\text { C. } \text { burmannii: } \\
2.14-9.30 \mathrm{~g} / \mathrm{kg}\end{array}$ & $\begin{array}{l}\text { (1) Coumarin } \\
\text { contents: } C \text {. } \\
\text { burmannii }>C \text {. } \\
\text { loureiroi }>C \text {. cassia } \\
>C \text {. verum } \\
\text { (2) Cinnamon } \\
\text { aldehyde contents: } \\
\text { C. } \text { cassia }>C \text {. } \\
\text { verum }\end{array}$ & $\begin{array}{l}\text { National Center } \\
\text { for Natural } \\
\text { Products } \\
\text { Research codes: } \\
\text { C. verum } 3997 \text {, } \\
3974 \text { - } 3987 \text {, } \\
4895,7545 ; \text { C. } \\
\text { burmannii } 3995 \text {, } \\
4881,4887 \text {, } \\
4892,4896, \\
4897,4898, \\
5605 ; \text { C. } \\
\text { loureiroi } 3996 \text {, } \\
\text { 5227; C. cassia } \\
\text { 5227, 5336, } \\
4893,4899\end{array}$ \\
\hline $\begin{array}{c}\text { Blahová \& } \\
\text { Svobodová } \\
\text { (2012) }\end{array}$ & $\begin{array}{l}\text { To determine the } \\
\text { coumarin content of } \\
\text { ground cinnamon in } \\
\text { the Czech retail } \\
\text { markets }\end{array}$ & $\begin{array}{l}\text { Powder of } \\
\text { unknown } \\
\text { cinnamon species } \\
(n=12)\end{array}$ & $\begin{array}{l}\text { Extraction: } \\
\text { Hot water } \\
\text { Analysis: } \\
\text { HPLC-UV }\end{array}$ & $2.65-7.02 \mathrm{mg} / \mathrm{kg}$ & 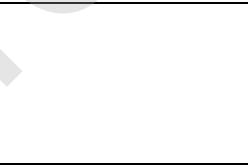 & $\begin{array}{l}\text { Purchased from } \\
\text { supermarkets } \\
\text { and a } \\
\text { specialized spice } \\
\text { market }\end{array}$ \\
\hline $\begin{array}{l}\text { Lvet al. } \\
(2010)\end{array}$ & $\begin{array}{l}\text { To develop a } \\
\text { reliable } \\
\text { quantification } \\
\text { method for the } \\
\text { constituents in } \\
\text { cinnamon }\end{array}$ & $\begin{array}{l}\text { C. cassia powder } \\
\text { of different } \\
\text { origins }(n=15)\end{array}$ & $\begin{array}{l}\text { Extraction: } \\
\text { Pressurised } \\
\text { liquid } \\
\text { extraction, ethyl } \\
\text { acetate, } 160^{\circ} \mathrm{C} \\
\text { Analysis: } \\
\text { GC-MS }\end{array}$ & $\begin{array}{l}0.33-6.50 \mathrm{~g} / \mathrm{kg} \\
(1.70 \pm 0.44 \\
\mathrm{g} / \mathrm{kg}, \mathrm{n}=15)\end{array}$ & $\begin{array}{l}\text { C. cassia contains } \\
\text { cinnamaldehyde: } \\
16.11-38.61 \mathrm{~g} / \mathrm{kg} \\
(25.6 \pm 1.5 \mathrm{~g} / \mathrm{kg}, \\
\mathrm{n}=15)\end{array}$ & $\begin{array}{l}\text { Authenticated } \\
\text { voucher } \\
\text { specimens } \\
\text { (CC01-CC15) } \\
\text { obtained from } \\
\text { local herbal drug } \\
\text { stores in } \\
\text { different parts of } \\
\text { China (deposited } \\
\text { at the Institute of } \\
\text { Chinese Medical } \\
\text { Sciences, } \\
\text { University of } \\
\text { Macau, Macao, } \\
\text { China). }\end{array}$ \\
\hline
\end{tabular}

